\title{
LA COMUNICACIÓN HORIZONTAL Y VERTICAL EN LOS SISTEMAS AMERICANO Y EUROPEO DE PROTECCIÓN DE DERECHOS HUMANOS A PROPÓSITO DEL DERECHO AL JUEZ NATURAL. HACIA UN DERECHO GLOBAL DE LOS DERECHOS HUMANOS
}

\author{
Alexandre H. Català i Bas y Marcela Ortíz Torricos \\ doi: http://dx.doi.org/10.18543/ed-65(1)-2017pp73-121
}

SuMARIO: 1. INTRODUCCIÓN. 2. MARCO NORMATIVO INTERNACIONAL. 3. DiÁlogo entre el TEDH y LA CIDH. 3.1. Juez competente. 3.2. Juez Independiente. 3.3. Juez imparcial. 4. DiÁlogo ENTRE EL TEDH y el Tribunal Constitucional español. 5. Diálogo entre LA CIDH Y TRIBUNALES CONSTITUCIONALES AMERICANOS (BoliVia, Colombia y Perú). 5.1. Juez competente. 5.2. Juez independiente. 5.3. Juez imparcial. 6. CONCLUSIONES.

\section{INTRODUCCIÓN}

Tras la Segunda Guerra Mundial se alcanzó el convencimiento de que la efectividad y garantía de los derechos humanos no era una cuestión doméstica de los Estados sino que era una prioridad de la Comunidad Internacional. Aparecen sistemas universales y regionales de protección de éstos con el claro mensaje de que si un estado quería formar parte de esa Comunidad Internacional debía aceptar que estos sistemas penetraran en sus fronteras y tuvieran la última palabra en cuanto a la protección de los derechos humanos en su territorio. El sistema europeo y el americano presentaban una particularidad: junto 
a una declaración de derechos se incluía un tribunal, Tribunal Europeo de Derechos Humanos (TEDH) y Corte Interamericana de Derechos Humanos (CIDH) respectivamente, que tenían competencia para juzgar casos elevados por los países miembros o por personas en ellos residentes. Y es que: «los derechos humanos deben ser protegidos en el plano internacional por un órgano judicial permanente, con jurisdicción compulsoria en materia contenciosa, al cual los individuos tengan el derecho de acceso», como entiende CANÇADO TRINDADE ${ }^{1}$.

Sus sentencias adquirían, por tanto, el efecto de cosa juzgada y de cosa interpretada. De acuerdo con LAMBERT, «el concepto de cosa juzgada (...), tiene como efecto poner fin a una controversia entre el individuo y el Estado (...). La cosa juzgada europea asegura la protección del individuo ante un orden estatal, responsable y juez a la vez. De otra parte, permite, sobre todo, que el Estado Parte respete sus obligaciones convencionales y participe en el desarrollo de valores europeos comunes $\rangle^{2}$.Ese efecto deriva inexcusablemente del vigente artículo 46 del Convenio Europeo de Derechos Humanos (CEDH) y del artículo 68 de la Convención Americana de Derechos Humanos cuando determina que los Estados Parte se comprometen a atajar o cumplir las sentencias definitivas de los respectivos Tribunales en los litigios en que sean parte. En relación con el segundo de estos efectos, el de cosa interpretada, destaca LINDE que poco se aportaría al sistema interno de protección con la introducción de una norma que a su vez necesita ser interpretada ${ }^{3}$. La existencia del TEDH y de la CIDH, encargado interpretar y aplicar el Convenio y la CIDH respectivamente en todos aquellos asuntos de los que conozca, es obliga a aceptar la interpretación que de los derechos y libertades contenidos en dichos instrumentos internacionales hagan estos Tribunales.

Ello supone que la autoridad de las sentencias se extiende de forma indirecta a los Estados no partes en el litigio ${ }^{4}$. En palabras de RUIZ MiguEL refiriéndose al sistema europeo, «las sentencias del TEDH pueden tener efectos sobre los no implicados en el asunto juzgado, si bien esos efectos no van a

1 Antonio Augusto CANÇADO TRINDADE, «El nuevo Reglamento de la Corte Interamericana de Derechos Humanos (2000) y su proyección hacia el futuro: La emancipación del ser humano como sujeto del derecho internacional» en El futuro de la Corte Interamericana de Derechos Humanos, (Costa Rica, San José: UNHCR, 2003), 93.

2 Elisabeth LAmBert, Les effets des arrêts de la Cour europeénne des droits de l' homme. Contribution à une approche pluraliste du droit européen des droits de l'homme, (Bruylant, 1999), 71.

${ }_{3}$ Enrique LINDE en et alii, El sistema europeo de protección de los derechos humanos, ed. Por Eduardo García de Enterría (Cívitas, 1978), 153-154.

${ }^{4}$ Gérard CoHEN-JonATHAN, «Quelques considérations sur l'autorité des arrêts de la Cour européenne des droits de l' homme» en Liber amicorum Marc-André Eissent, (Bruylant, 1995), 53. 
tener la fuerza de cosa juzgada, en la medida en que estos terceros no fueron parte en el proceso. Este efecto radiactivo es el efecto de cosa interpretada $\rangle^{5}$. En este sentido, en la STEDH Irlanda c. Reino Unido de 18 de enero de 1978, el TEDH afirmó que:

«[sus] sentencias sirven no solamente para solucionar el caso en las que son dictadas, sino más ampliamente para clarificar, salvaguardar y desarrollar las normas de la Convención, y a contribuir al respeto de los Estados a las obligaciones que han asumido en su calidad de Partes Contratantes» (Párf. 158).

En esa misma línea se pronunció la CIDH en la Opinión Consultiva n. ${ }^{\circ} 17 / 02$, en la que al referirse al contenido de dicha opinión se señala que en la misma se «da un notable aporte a la construcción jurisprudencias de las obligaciones erga omnes de protección de los derechos de la persona humana» ${ }^{6}$.

Ello ha sido propiciado por disposiciones constitucionales que así lo establecen. Por citar dos ejemplos, de acuerdo con el artículo 10. 2 de la Constitución española y el 13.IV de la Constitución boliviana los derechos en ellas reconocidos se interpretarán de conformidad con los Tratados internacionales de derechos humanos ratificados por los respectivos países. El Tribunal Constitucional español en su sentencia 114/1984, de 29 de noviembre hablará de: «vía interpretativa impuesta por el artículo 10.2 de la Constitución» y en la 5/1985, de 23 de enero, admite que la referencia a la jurisprudencia del TEDH viene impuesta por el mandato constitucional contenido en el artículo 10.2 CE. Delgado Barrio concluye, a la vista de la jurisprudencia del Tribunal Constitucional español, que «puede perfectamente apreciarse cómo el primer itinerario hermenéutico del Tribunal Constitucional es

${ }^{5}$ Carlos Ruiz Miguel, La ejecución de las sentencias..., 52-53. Sobre la cuestión del valor de la jurisprudencia del TEDH en el ordenamiento español, vide, por todos, Enrique LINDE, El sistema europeo..., 153-4; Javier DElgado BARRIO, Proyección de las decisiones..., 243; José María Morenilla RodríGUez, La ejecución de las sentencias..., 53 y ss.; Manuel Martínez Sospedra El Convenio de Roma..., 891 y ss.; Fernando ReY MARTíNEZ, «El Criterio interpretativo de los Derechos Fundamentales conforme a normas internacionales (Análisis del artículo 10.2 CE)», Revista General de Derecho, n. ${ }^{\circ}$ 537, (1989), 3616-3617; Lorenzo M. Bujosa VAdell, Las sentencias del tribunal...; Ana SALAdo OsunA, «Efectos y ejecución de las sentencias del Tribunal Europeo de Derechos Humanos en derecho español», en Cuadernos de derecho Judicial, jurisprudencia del tribunal Europeo de Derechos Humanos II, ed. por Consejo General del Poder Judicial, (1995), 190 y ss., Manuel Ortells Ramos. «El juez ante el Convenio europeo de Derechos Humanos y ante las sentencias del Tribunal Europeo de Derechos Humanos», en Seminario sobre Jurisprudencia del Tribunal Europeo de Derechos Humanos ed. Por Generalitat Valenciana, (1998), 22 y ss.

${ }^{6}$ Voto concurrente del Juez Cançado Trindade, en la OC 17/02 de 28 de agosto de 2002, que se refiere a la condición jurídica y derechos humanos del niño. 
siempre (...) el que conduce a la jurisprudencia del Tribunal Europeo» ${ }^{7}$. El Tribunal Constitucional del Perú, Expediente 2730-2006-PA/TC, Sentencia de 21 de julio de 2006, manifestó, por su parte, que las sentencias de la CIDH: «resultan vinculantes para todo el poder público nacional, incluso en aquellos casos en los que el Estado no ha sido parte en el proceso». Y es que, de acuerdo con GARCÍA FALCONÍ, se tiene que las decisiones de este tribunal internacional son vinculantes: "no solo en su parte decisoria que afecta al país procesado específicamente (cosa juzgada), sino en sus consideraciones o ratio decidendi (cosa interpretada), en las cuales se desarrolla la interpretación obligatoria de la normas de la Convención» ${ }^{8}$.

Es una realidad, por lo tanto, que no nos encontramos ante dos sistemas, el convencional y el nacional, aislados o separados sino que, en el seno de una relación vertical, se observa una clara influencia del primero sobre el segundo. Aunque, en los últimos tiempos esta comunicación se ha convertido en bidireccional pues también existe de los tribunales estatales hacia el TEDH. Ello no obstante, la intensidad de la primera es mucho mayor que la segunda.

Por otra parte, es objeto de estudio las relaciones entre los dos sistemas de protección de los derechos humanos, enmarcado en una comunicación horizontal y bidireccional aunque esa bidireccionalidad no supone que las dos vías contengan una comunicación de similar intensidad siendo mucho más intensa la que va del TEDH a la $\mathrm{CADH}^{9}$.

A la hora de estudiar estas cuestiones, gran parte de la doctrina se ha decantado por utilizar la expresión, de origen anglosajón, diálogo entre tribunales (jurisdictional dialogue ${ }^{10}$. Ello no obstante, su uso casi generalizado

7 Javier Delgado Barrio, «Proyección de las decisiones del Tribunal Europeo de Derechos Humanos en la jurisprudencia española», Revista de Administración Pública, n. ${ }^{\circ} 119$, (1989): 247.

${ }^{8}$ Ramiro GARCÍA FALCONí: «Son obligatorias para los jueces nacionales las decisiones de los Tribunales Internacionales de Protección de Derechos Humanos y específico de la Corte Interamericana de Derechos Humanos» en Temas fundamentales de derecho procesal penal, (Quito: Ed. Cevallos, 201), 78.

9 Así lo destacan Javier García Roca, Humberto Nogueira Alcalá y Rafael BusTOS GISBERT: «La comunicación entre ambos sistemas y las características del diálogo», en: El diálogo entre los sistemas europeo y americano de Derechos Humanos, ed. Por Javier García Roca, Pablo Antonio Fernández, Pablo Santolaya, Raúl Canosa (Civitas, 2012), 76.

${ }^{10}$ A título de ejemplo Rafael Bustos GisBert, «XV proposiciones generales para una teoría de los diálogos judiciales», Revista española de Derecho Constitucional, n. ${ }^{\circ}$ 95, (2012), 13 a 63; Javier García Roca, Pablo Antonio Fernández, Pablo SAntolaya, Raúl CANOSA: El diálogo entre los sistemas op. cit. Luis LóPEZ GUERRA, «El diálogo entre el Tribunal Europeo de Derechos Humanos y los Tribunales españoles. Coincidencias y divergencias», Teoría y Realidad Constitucional; Luis JIMENA QUESADA: Jurisdicción nacional y control de convencionalidad. A propósito del diálogo judicial global y de la tutela 
no ha estado exento de reticencias ${ }^{11}$ o críticas $^{12}$. LOPEZ GUERRA, define el diálogo como proceso de influencias y relaciones recíprocas entre tribunales $\rangle^{13}$. Mantiene BUSTOS unas postura más restringida sobre qué hay que entender por diálogo al definirlo como «la comunicación entre tribunales derivada de una obligación de tener en cuenta la jurisprudencia de otro tribunal (extranjero o ajeno al propio ordenamiento jurídico) para aplicar el propio Derecho» ${ }^{14}$, dejando fuera a las influencias que pueden darse entre tribunales sin que exista obligación alguna, lo que en su opinión coincidente con la de VERGOTTINI no es más que un recurso a la comparación ${ }^{15}$.

Se ha detectado esa comunicación bidireccional dentro del sistema europeo, aunque sigue siendo predominante la vía que va del TEDH a los tribunales estatales. Asimismo existe esa bidireccionalidad entre el sistema europeo y americano. También aquí la influencia del TEDH es mayor. Poner de relieve que en esa comunicación no sólo habrá coincidencias sino que pueden darse «discrepancias e incluso oposiciones» ${ }^{16}$.

La comunicación entre tribunales, no ha de tender necesariamente hacia una homogeneización o identidad pero si, hacia la armonización que permita

multinivel de derechos, (Aranzadi, 2013); Alejandro SAIZ ARNAIZ: «Tribunal Constitucional y Tribunal Europeo de Derechos Humanos: las razones para el diálogo» en Tribunal Constitucional y diálogo entre tribunales, ed. Po VV.AA. (CEPC, 2013), 131 a 159.

${ }^{11}$ García Roca, Nogueira Alcalá y Bustos Gisbert, aunque se decantan por estos términos reconocen que a pesar de «haberlo dudado» optaron «por manejar esta expresión por su valor pedagógico y porque ha acabado por imponerse en la práctica (p. 66). Señalan que «esta indeterminación de la idea de diálogo posee la ventaja -y el inconveniente- de su tremenda flexibilidad para describir nuevos fenómenos (p. 74). Javier GARcía RocA, Humberto Nogueira Alcalá, y Rafael Bustos Gisbert, «La comunicación entre ambos sistemas y las características del diálogo», en Javier García RocA, Pablo ANTONIO FeRNÁNDEZ, Pablo Santolaya, Raúl CANOSA: El diálogo entre..., op. cit. el propio Garcia Roca llega a afirmar que «si bien no es claro qué quiere decirse con "diálogo", puede que de esta ambigüedad sea mejor no salir». Javier GARCíA RocA: «El diálogo entre el Tribunal Europeo de Derechos Humanos y los tribunales constitucionales en la construcción de un orden público europeo», Teoría y Realidad Constitucional, n. ${ }^{\circ} 30,2012$, p. 223 . Xiol Ríos describe considera que las objeciones a este concepto no tienen entidad suficiente para rechazar este concepto. Xiol Ríos: «El diálogo entre tribunales», en VVAA, Tribunal Constitucional y diálogo entre tribunales, Cuadernos y Debates n. ${ }^{\circ}$ 231, Centro de Estudios Políticos y Constitucionales, 2013, pp. 34-35.

${ }^{12}$ Giuseppe de Vergottini, Más allá del diálogo entre tribunales. Comparación y relación entre jurisdicciones, (Civitas, 2010); y «El diálogo entre tribunales», Teoría y Realidad Constitucional, n. ${ }^{\circ} 28,(2011), 335$ a 352.

13 LÓPEZ GUERra, El diálogo entre..., 139 a 158.

14 Bustos GisBert, XV proposiciones generales..., 21.

15 Giuseppe de Vergottini, Más allá del diálogo..., 40.

16 Javier García Roca, Humberto Nogueira AlcalÁ, y Rafael Bustos Gisbert, La comunicación entre ambos sistemas ..., 77. 
afirmar la compatibilidad ${ }^{17}$ de dos construcciones jurisprudenciales. Ello permite plantearnos ya la existencia de un derecho global de los derechos humanos aunque para afianzar esta idea habría que acudir al análisis de otros sistemas, lo que excede del objetivo de este estudio.

En las páginas que vienen a continuación, se analiza la comunicación intra y extra sistemas de protección en relación al derecho a un juez natural. Así se estudia la producida entre la jurisprudencia del TEDH y la del Tribunal constitucional español, entre la jurisprudencia del TEDH y la CIDH y entre ésta última y la jurisprudencia de los tribunales constitucionales de la región andina (Bolivia, Perú y Colombia). Dejamos para un posterior estudio el análisis de la existencia o no de obligaciones jurídicas en estas relaciones.

\section{MARCO NORMATIVO INTERNACIONAL}

Entre los instrumentos internacionales que consagra el mencionado derecho al juez natural, está el art. XXIV de la Declaración Americana de los Derechos y Deberes del Hombre de 1948 señala que: «Toda persona tiene derecho de presentar peticiones ... a cualquier autoridad competente ... obtener pronta resolución». A su vez, el art. 14.1 del Pacto Internacional de Derechos Civiles y Políticos de 16 de diciembre de 1966 se refirió al derecho de las personas a ser: «oída públicamente y con las debidas garantías por un tribunal competente, independiente e imparcial, establecido por la ley».

El CEDH de 4 de noviembre de 1950, en su art. 6.1, como parte de un proceso equitativo, regula el derecho que tiene toda persona, de ser oída por un Tribunal independiente e imparcial, establecido por la ley, que decidirá los litigios sobre sus derechos y obligaciones de carácter civil o sobre el fundamento de cualquier acusación.

En el mismo sentido se ha regulado el art. 8.1 de la CADH de 22 de noviembre de 1969, que establece que toda persona tiene derecho a ser oída, con las debidas garantías, por un juez o tribunal competente, independiente e imparcial, establecido con anterioridad por la ley, en la sustanciación de cualquier acusación penal u obligaciones de orden civil, laboral, fiscal o de cualquier otro carácter.

En ambos casos se está refiriendo al derecho al debido proceso, que tienen las personas de participar en demanda y/o en defensa del reconocimiento de sus pretensiones jurídicas e intereses que resultan ser controvertidos, por lo

17 Alejandro SAIz ARNAIz: «Tribunal Constitucional y Tribunal Europeo de Derechos Humanos: las razones para el diálogo», en Tribunal Constitucional y diálogo entre tribunales, ed. Por VV.AA. (Centro de Estudios Políticos y constitucionales: Cuadernos y Debates, n. $\left.{ }^{\circ} 213,2013\right), 136$. 
que también gozan del derecho a un juez natural, a efectos de que sea una autoridad jurisdiccional (juez o tribunal) -competente, independiente e imparcial y establecido por ley anterior- el que resuelva sus controversias jurídicas, acorde al derecho y la justicia que nace de las leyes, así como de la Constitución y normas internacionales de protección de los Derechos Humanos.

\section{DIÁLOGO ENTRE EL TEDH Y LA CIDH}

De la jurisprudencia de ambos tribunales se deduce que no pretenden organizar de manera perfecta a los órganos jurisdiccionales: «sino de garantizar derechos de los justiciables ... al ejercicio de las funciones jurisdiccionales por un órgano establecido en la ley y del cual pueden predicarse las notas de imparcialidad e independencia» ${ }^{18}$; de ahí que se puede hablar del derecho que se tiene a un juez competente (establecido por la ley), independiente e imparcial, que se pasa a analizar.

\subsection{Juez competente}

El derecho a un juez natural, debe satisfacer una de sus exigencias, cual es que la autoridad jurisdiccional sea competente, que resulta ser un elemento funcional, pues un Tribunal debe ser competente para adoptar decisiones jurídicamente vinculantes, es que: «un poder de decisión es inherente a la verdadera noción de Tribunal dentro del significado del Convenio», como en 1985 entendió el TEDH ${ }^{19}$, asimismo ese Tribunal en 1985 consideró que: «un Tribunal se caracteriza en el sentido sustantivo del término por su función judicial, es decir, por resolver asuntos dentro de su competencia sobre la base de reglas jurídicas y conforme a procedimientos conducidos de manera preestablecida $»^{20}$.

La CIDH, en 1999 considera que: «Constituye un principio básico relativo a la independencia de la judicatura que toda persona tiene derecho a ser juzgada por tribunales de justicia ordinarios con arreglo a procedimientos legalmente establecidos $\rangle^{21}$; la interpretación realizada por la CIDH, no es precisamente la más afortunada, al considerar la independencia, como un

18 Javier García Roca y José Miguel Vidal ZAPATERO, «El derecho a un tribunal independiente e imparcial (art. 6.1): una garantía concreta y de mínimos antes que una regla de la justicia» en La Europa de los derechos: el Convenio Europeo de Derechos Humanos, (Centro de Estudios Políticos y Constitucionales, 2. a edición), 404.

19 Caso Benthem Vs. Holanda, Sentencia de 23 de octubre de 1985.

${ }^{20}$ Caso Belilos Vs. Suiza, Sentencia de 29 de abril de 1988.

${ }^{21}$ Caso Castrillo Petruzzi Vs. Ecuador. Sentencia de 30 de mayo de 1999, párr. 129. 
principio básico del derecho a ser juzgado con arreglos a procedimientos establecidos, cuando precisamente los procedimientos y normas legales, son los que determinan la competencia del juzgador y no la independencia, como correctamente y en la misma línea, se reconoció previamente, por el TEDH.

El derecho a ser juzgado por un juez natural, cuya competencia sea establecida con anterioridad por la ley, implica la constitución de un órgano jurisdiccional legal, que se expresa en: «El derecho a ser juzgado por un tribunal cuya composición (y competencia) obedezca a la ley» y no solo a la voluntad de los interesados, como entendió el TEDH en 1992 22 ; en consecuencia, primero es la ley la que establece la competencia de una autoridad, que sobre esa base juzga, asegurándose que los procesos sean resueltos por autoridades con potestad jurisdiccional y competencia, no por jueces o tribunales $a d-h o c$, creados para resolver un caso, donde habrá vulneración al derecho al juez natural, como entendió el TEDH en 2002, cuando señaló que «un órgano que no haya sido establecido conforme a la voluntad del legislador (tribunal ad-hoc) está necesariamente desprovisto de legitimidad ... para resolver conflictos entre particulares $\rangle^{23}$, por carecer de competencia legal.

Es que solo cuando existe un juez o tribunal «'establecido por la ley" concierne a la 'previsibilidad', según la ley» ${ }^{24}$, se está frente a una autoridad jurisdiccional, que de acuerdo a las reglas de procedimiento, es competente para examinar y resolver un caso, por no ser parte de un tribunal especial $o$ ad hoc; en ese sentido, se pronunció la CIDH, en innumerables casos, cuando señaló que la finalidad de un juzgamiento por un tribunal competente, establecido por ley anterior, es evitar que las personas sean juzgadas por tribunales especiales o ad-hoc; también se expresó que se vulnera el derecho a ser oído por juez o tribunal establecidos con anterioridad por la ley, cuando se designa a uno que es ad-hoc para el caso sub judice s. $^{25}$.

El razonamiento dado por estos Tribunales, implica, por una parte, que «será el órgano legislativo el que decida la organización y la jurisdicción de los tribunales de un Estado ${ }^{26}$ a través de las leyes que al efecto emita; por otra parte los jueces o tribunales de justicia o funcionarios del Estado con poder jurisdiccional, tienen que actuar con arreglo a las normas y procedimientos establecidos en la ley, asimismo deben actuar conforme a la competencia que

${ }^{22}$ Caso Pfeifer y Plankl Vs. Austria, Sentencia de 25 de febrero de 1992, parr. 38.

${ }_{23}$ Caso Lavents Vs. Letonia, Sentencia de 28 de noviembre de 2002.

${ }^{24}$ Javier García Roca y José Miguel Vidal Zapatero, El derecho..., 370.

${ }^{25}$ Caso Castillo Petruzzi Vs. Perú de 1999, Caso Cesti Hurtado Vs. Perú de 1999, Caso Ivcher Bronsein Vs. Perú de 2001, Caso Apitz Barbera Vs. Venezuela de 2008, entre muchos otros.

${ }^{26}$ Cecilia Medina Quiroga, La Convención Americana: Teoría y Jurisprudencia, (Chile, Santiago: Universidad de Chile, Centro de Derechos Humanos, 2005), 294. 
le señaló la ley, por lo que esa facultad constituye: «un requisito que impide al poder político la alteración interesada de la competencia natural de los tribunales y sus procedimientos $\gg^{27}$, asegurándose así la efectividad y el cumplimiento del derecho al juez natural de todas las personas.

Los desarrollos antes mencionados, evidencian como de la jurisprudencia del TEDH parten los desarrollos que realiza la CIDH; sin embargo, tratándose del elemento competencia del juez natural, en el tema de jurisdicción y competencia militar, se produce un fenómeno inverso en la medida que las interpretaciones realizadas por la CIDH, son asumidas por el TEDH. Probablemente ello se deba a una realidad que caracterizó a una buena parte del continente americano, especialmente en las décadas de los 70 y 80 , que fue la existencia de gobiernos militares que vinieron acompañados de jurisdicciones militares que en su actuación se caracterizaron por ser violatorias del derecho al juez natural, en su elemento competencia, provocando que ese tipo de irregularidades fueran llevadas ante la por la CIDH.

Hay que recordar que América, es un: «continente en el que la jurisdicción militar ha tendido muchas veces a ser expansiva» ${ }^{28}$, en la medida en que su historia se ha visto afectada por militarismos que han creado tribunales ad-hoc o fueros de privilegio, que de manera reiterada y sistemática han usurpado funciones judiciales, violando el derecho a un juez natural y competente, cuando han asumido la jurisdicción ordinaria para procesar a civiles o para procesar a militares por delitos que hubieran correspondido conocer a tribunales ordinarios.

Esa situación ha motivado a las víctimas de atropellos a sus derechos humanos ${ }^{29}$ a plantear reclamos internos, que al no haber tenido ningún eco, han acabado en demandas internacionales resueltas por la $\mathrm{CIDH}$, que, a su

${ }^{27}$ Claudio Nash Rojas: Reseña de la Jurisprudencia de la Corte Interamericana de Derechos Humanos (2008), 127. Este comentario está disponible en: www.anuariocdh. uchile.cl.

28 Diego GARCÍA-SAYÁN, «Una Viva Interacción: Corte Interamericana y Tribunales Internos», en La Corte Interamericana de Derechos Humanos. Un Cuarto de Siglo: 19792004, (San José C.R: CIDH, 2005), 52.

${ }^{29}$ Los problemas de vulneración a los derechos humanos por militares, no es un tema que se hubiera estancado en la década de los 70 u 80 en América Latina con el Plan Cóndor $\mathrm{u}$ otras organizaciones de militares, contra opositores de sus dictaduras o de los gobiernos a los que han apoyado; sino también abarca la década de los 90 y de una u otra manera, aunque de de manera general de forma más morigerada, se extienden hasta nuestros días, para ello basta analizar el Informe Alerta 2010 sobre los Conflictos, Derechos Humanos y Construcción de Paz (Escola de Cultura de Pau. 1 mínima, 192 máxima, en el que evidencia como en los países en estudio), donde se evidencia como en Bolivia hay 78, Colombia 26, Perú 96, Chile 142 y Venezuela 77, de casos registrados de vulneración de derechos humanos por militares; como se desarrolló por Juan Sebastián Gómez y Paré Ortega, Militarismo en América Latina, (Barcelona-España: Justícia i Pau, 2010), 34. 
vez, desarrolló una importante doctrina de protección al derecho al juez natural (competente), que no ha sido la misma en todos los tiempos, sino que gracias a una evolución positiva de protección, ha logrado revertir prácticas perniciosas y violatorias del derecho al juez competente, independiente e imparcial, tarea que indudablemente no ha sido fácil y menos rápida, sino producto de una construcción doctrinal desarrollada en el tiempo, que finalmente ha sido asumida por tribunales o Cortes de la región andina.

En el caso Genie y Lacayo (que dio lugar a la Sentencia de 29 de enero de 1997), en la relación de antecedentes, se tiene la posición que asumió la $\mathrm{CIDH}$, que consideraba que juzgar delitos comunes como si fueran militares -por el sólo hecho de haber sido ejecutados por militares-, es violatorio al derecho al juez natural ${ }^{30}$, sin embargo de ello y haciendo caso omiso a ese razonamiento la CIDH en su valoración consideró que el que se: «trate de una jurisdicción militar no significa per se que se violen los derechos humanos que la Convención garantiza a la parte acusadora ${ }^{31}$; es decir que de inicio no se reconoció que los militares estarían violando el derecho a un juez natural, cuando juzgaban delitos comunes.

A unos días de emitido ese razonamiento, la propia Corte lo cambio, en Sentencia de 17 de septiembre de 1997, en el Caso Loayza Tamayo Vs. Perú ${ }^{32}$, en la que se refirió que la de manera expresa a que: «la jurisdicción militar del Perú violó el artículo 8.1 de la Convención, en lo que concierne a la exigencia de juez competente ... al dictar sentencia firme absolutoria», pues considera que: «la jurisdicción militar carecía de competencia para mantenerla en detención y menos aún para declarar, en el fallo absolutorio de última instancia ... Con esta conducta los tribunales castrenses actuando ultra vires usurparon jurisdicción e invadieron facultades de los organismos judiciales ordinarios $\rangle^{33}$; lo que significa que la jurisdicción militar al disponer la detención y dictar sentencia contra una persona particular, por supuestos ilícitos de tipo común, han usurpado funciones de la jurisdicción ordinaria, actuando por tanto sin competencia y violando derechos humanos garantizados por la Convención, como es el derecho a un juez natural (usurpación de jurisdicción y actuación sin competencia).

\footnotetext{
30 Párrafo 53.

31 Párrafo 84.
}

${ }^{32}$ El caso tiene como antecedentes fácticos, que una persona particular, como es la señora María Elena Loayza Tamayo, peruana, profesora de la Universidad San Martín de Porres, fue arrestada por el Estado Peruano en 06 de febrero de 1993, sin orden expedida por la autoridad judicial competente, como presunta colaboradora del grupo subversivo Sendero Luminoso; la jurisdicción militar del Perú dictó a su favor sentencia absolutoria por el delito de traición a la patria del cual fue acusada.

33 Párrafo 61. 
La violación del derecho en estudio, también ha sido analizada desde el punto de vista de la competencia militar, que está dada y establecida para juzgar delitos militares, siendo otra la competencia de los jueces ordinarios para juzgar delitos comunes y un traslado de competencia, significa vulneración al derecho al juez natural, así se entendió en Sentencia de 29 de mayo de 1999, en el Caso Castillo Petruzzi y otros c. Perú34, en la que se manifestó que el: «traslado de competencias de la justicia común a la justicia militar ... supone excluir al juez natural ... Cuando la justicia militar asume competencia sobre un asunto que debe conocer la justicia ordinaria, se ve afectado el derecho al juez natural y, a fortiori, el debido proceso, el cual, a su vez, encuentra se íntimamente ligado al propio derecho de acceso a la justicia» ${ }^{35}$ (traslado de competencia).

En consecuencia, por el tema de traslado de competencia, en el caso concreto se llegó a la conclusión de que la jurisdicción militar, no es la natural para juzgar a civiles que carecen de funciones militares; ese razonamiento se ha mantenido por la Corte en posteriores casos, así: en Sentencia de 18 de agosto de 2000 en el Caso Cantoral Benavides Vs. Perú ${ }^{36}$; como en la Sentencia de 06 de diciembre de 2001 en el Caso Las Palmeras Vs. Colombia ${ }^{37}$; también en Sentencia de 05 de julio de 2004, en el Caso 19 Comerciantes Vs. Colombia $^{38}$; en igual sentido lo señalado en Sentencia de 25 de noviembre de 2004, en el Caso Lori Berenson Mejía Vs. Perú ${ }^{39}$.

Igualmente, el indicado Caso Castillo Petruzzi y otros, resulta ser emblemático, pues además de la posición doctrinal referida (traslado de competencia) desarrolló otra posición doctrinal relativa a la obligación negativa del Estado, en sentido que: «El Estado no debe crear «tribunales que no apliquen normas procesales debidamente establecidas para sustituir la jurisdicción que corresponda normalmente a los tribunales ordinarios ${ }^{40}$; lo que significa que en un razonamiento más amplio, el Estado no solamente está impedido de

${ }^{34}$ La situación fáctica que tiene como base esta acción se encuentra en la detención de los señores Jaime Francisco Castillo Petruzzi y otros, entre el 14 y 15 de octubre de 1993, por DINCOT que fue un órgano del Estado encargado de prevenir, denunciar y combatir las actividades de traición a la patria por actos terroristas; finalmente procesados ante la justicia militar, por el delito de traición a la patria en el fuero militar.

35 Párrafo 128.

36 Párrafo 112.

37 Párrafo 52.

38 Párrafo 167.

39 Párrafo 141.

${ }^{40}$ Párrafo 129, que en su pie de página, cita su fuente original que es: «Principios Básicos Relativos a la Independencia de la Judicatura, adoptadas por el Séptimo Congreso de las Naciones Unidas sobre Prevención del Delito y Tratamiento del Delincuente, celebrado en Milán del 26 de agosto al 6 de septiembre de 1985, y confirmados por la Asam- 
trasladar competencias, sino que no puede sustituir la jurisdicción ordinaria por la jurisdicción militar, aplicando normas procesales previamente establecidas de lo uno hacia lo otro (sustitución de jurisdicción). Ese razonamiento se ha mantenido en la Sentencia de 25 de noviembre de 2004, en el Caso Lori Berenson Mejía Vs. Perú ${ }^{41}$.

Donde se aclara con mayor precisión el alcance restrictivo de la jurisdicción penal militar o sus límites, es en la Sentencia de 16 de agosto de 2000, en el Caso Durand y Ugarte Vs. Perú ${ }^{42}$, en la que se indicó que: «En un Estado democrático de Derecho la jurisdicción penal militar ha de tener un alcance restrictivo y excepcional y estar encaminada a la protección de intereses jurídicos especiales, vinculados con las funciones que la ley asigna a las fuerzas militares ... sólo debe juzgar a militares por la comisión de delitos o faltas que por su propia naturaleza atenten contra bienes jurídicos propios del orden militar» ${ }^{43}$; significa que el límite de la actuación de la jurisdicción militar está en juzgar delitos que atenten bienes jurídicos militares; en esa medida se excluye la posibilidad de que la jurisdicción militar juzgue a civiles, además se descarta la posibilidad de que sus miembros (militares) sean juzgados por esa jurisdicción militar por delitos comunes -para eso está la jurisdicción ordinaria- (alcance de la jurisdicción militar).

Ese alcance de la jurisdicción militar ha sido ratificado en forma posterior por la Corte, cuanto emitió la indicada Sentencia de 05 de julio de 2004, en el Caso 19 Comerciantes Vs. Colombia ${ }^{44}$; o lo expresado en la Sentencia de 22 de noviembre de 2005, en el Caso Palamara Iribarne Vs. Chile ${ }^{45}$, en el que además en la misma línea se señaló: «la facultad de conocer las causas civiles y criminales de la jurisdicción militar, «de juzgarlas y de hacer ejecutar lo

blea General en sus resoluciones 40/32 de 29 de noviembre de 1985 y 40/146 de 13 de diciembre de 1985».

${ }^{41}$ Párrafo 143.

42 Tiene como antecedentes lo sucedido el 14 y 15 de febrero de 1986, cuando fueron detenidos Nolberto Durand Ugarte y Gabriel Pablo Ugarte Rivera, respectivamente, por efectivos de la Dirección contra el Terrorismo -DIRCOTE- bajo sospecha de haber participado en actos de terrorismo; procesados por la jurisdicción militar.

${ }^{43}$ Párrafo 117.

44 Párrafos 165 y 173. Este caso resulta ser interesante, pues tiene origen el 6 de octubre de 1987, cuando comerciantes (víctimas) pasaron por el caserío de Puerto Araujo, donde fueron requisadas por miembros de las Fuerzas Militares, verificando si éstos llevaban o no armas; en la tarde fueron detenidos por miembros de un grupo «paramilitar» y dieron muerte a los 17 comerciantes; esto motivo el juzgamiento de los militares vinculados en la investigación, por jueces penales militares, sin considerarse que por el tipo de delito (común), debía ser juzgados por la jurisdicción ordinaria, produciéndose la violación al derecho al juez competente.

45 Párrafo 124. 
juzgado» pertenece exclusivamente a los tribunales militares establecidos en el mismo Código» ${ }^{46}$; entre otros casos.

Esos criterios desarrollados por la CIDH han sido recogidos pero no asumidos estrictamente por el TEDH, en el Caso Ergin Vs. Turquía, de 5 de mayo de 2006. Si la CIDH en el caso Durand Ugarte, tal como hemos visto, excluye del ámbito de la jurisdicción militar el juzgamiento de civiles y sólo debe juzgar a militares por la comisión de delitos o faltas que por su propia naturaleza atenten contra bienes jurídicos propios del orden militar, el TEDH mantiene que «no puede sostener que el Convenio excluya absolutamente la competencia de los tribunales militares para conocer de asuntos que impliquen a civiles. Sin embargo, tal caso deberá ser objeto de un examen especialmente riguroso ${ }^{47}$. Ahora bien, el Tribunal es consciente de los peligros que entraña que civiles sean juzgados por tribunales militares, por lo que advierte que solo en casos excepcionales puede un tribunal militar juzgar a un civil sin vulnerar el artículo 6 del $\mathrm{CEDH}^{48}$, de tal manera que «la jurisdicción militar no puede extenderse a los civiles salvo que existan razones imperiosas que justifiquen tal situación basándose en una base legal clara y previsible. La existencia de tales razones habrá que ser demostrada en cada caso concreto. La atribución de ciertas categorías de delitos a la jurisdicción militar hechas in abstracto por la legislación natural no sería suficiente» ${ }^{49}$.

Para llegar a este conclusión hace referencia al informe sobre la cuestión de la administración de justicia por los militares, que en el seno de la ONU se sometió a la Comisión de Derechos Humanos, que lo debatió en la 62. ${ }^{a}$ sesión en 2006 (Doc. E/CN.4/Sub.2/2005/9 de 16 de junio 2005) y en cuyo, Principio . $^{\circ} 5$ se afirma que «los tribunales militares ... no son competentes para juzgar a civiles. En todo caso, el Estado deberá garantizar que los civiles acusados de un delito de cualquier naturaleza sean juzgados por tribunales

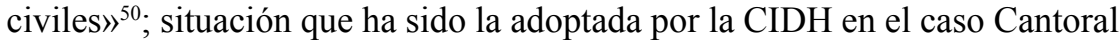
Benavides Vs. Perú, en Sentencia de 18 de agosto de 2000, en la que se expresó que tribunales militares han sido creado por varias leyes con el objetivo de mantener el orden y la disciplina dentro de las fuerzas armadas. Por ello, su aplicación se reserva a los militares que hayan incurrido en delitos o faltas en el ejercicio de sus funciones $\rangle^{51}$.

\footnotetext{
${ }^{46}$ Párrafo 149.

47 Párrafo 42.

48 Párrafo 44.

49 Párrafo 47.

${ }^{50}$ Caso Ergin Vs. Turquía, Sentencia de 05 de abril de 2006, párr. 45.
}

${ }^{51}$ Como se ha referido en la sentencia del TEDH citada supra, remitiéndose al fallo de la CIDH, relativo al Caso Cantoral Benavides Vs. Perú, Sentencia de 18 de agosto de 2000, párr. 112. 
No hay una asunción de la jurisprudencia de la CIDH pero si una toma en consideración. El TEDH no ha llegado a la conclusión de la CIDH de impedir a los tribunales militares juzgar a civiles pero si somete esa posibilidad a una serie de exigencias que la hacen prácticamente inviable. El nivel de protección de la CIDH, el estándar americano, es más alto que el dispensado por el europeo pero las exigencias del TEDH hacen que en la práctica esa diferencia disminuya, aunque, eso sí, no desaparece. Podríamos afirmar que la CIDH ha llegado a buen puerto en su razonamiento y que el TEDH está en plena travesía (es decir, en plena evolución de su jurisprudencia) hacia el mismo destino. La referencia al Informe y al caso Durand y Ugarte como puntos de referencia puede entenderse en este sentido y como un aviso a navegantes de una futura postura similar a la de la CIDH.

\subsection{Juez Independiente}

El elemento de independencia, del derecho al juez natural, implica la existencia de un Tribunal, que «debe también satisfacer una serie de requerimientos (como es la) independencia, en particular del poder ejecutivo», como en 1988 entendió el TEDH. En consecuencia la independencia implica la existencia de un órgano que imparte jurisdicción, pero que está ajeno a presiones concretas; por eso se entiende por independencia: «la imposibilidad jurídica de dirigir instrucciones o recomendaciones a los miembros de un órgano judicial (u otro órgano que ejerza jurisdicción) en relación con su actividad jurisdiccional», reforzándose la dependencia de la ley y la independencia del juzgador.

De manera general, la facultad jurisdiccional debe ejercerse con independencia y no es una atribución exclusiva de las autoridades del órgano judicial, sino que alcanza a la actividad jurisdiccional que pueden realizar otras autoridades del Estado, que tienen funciones legislativas o administrativas; en tales casos, cuando un órgano colegiado tenga otras funciones -además administrativas-, no le impide ser un Tribunal cuando ejerza su función judicial, como reconoció expresamente el TEDH en 1984, esta posición del Tribunal Europeo: «supone renunciar exigir a los Estados firmantes una exclusividad judicial que, sin embargo, se desprende naturalmente de un entendimiento moderno de las reglas de la división de poderes».

Realizando una remisión expresa y específica al razonamiento del TEDH, la CIDH el $2001^{52}$, en la misma línea consideró que de conformidad al principio de separación de poderes o distribución de funciones, cualquier autoridad pública -sea administrativa, legislativa o judicial- puede ejercer -con

\footnotetext{
52 Sentencia de 31 de enero de 2001, en el Caso del Tribunal Constitucional Vs. Perú.
} 
independencia- función jurisdiccional, es que cualquier órgano del Estado que ejerza funciones materialmente jurisdiccionales, tiene la obligación de garantizar el derecho al juez natural independiente.

En la indicada línea, en dicha Sentencia se manifestó: «De conformidad con la separación de los poderes públicos que existe en el Estado de Derecho, si bien la función jurisdiccional compete eminentemente al Poder Judicial, otros órganos o autoridades públicas pueden ejercer funciones del mismo tipo» ${ }^{53}$, aclarando a continuación que cuando la: «Convención se refiere al derecho de toda persona a ser oída por un «juez o tribunal competente» para la «determinación de sus derechos», esta expresión se refiere a cualquier autoridad pública, sea administrativa, legislativa o judicial, que a través de sus resoluciones determine derechos y obligaciones de las personas $\rangle^{54}$; lo que implica que el Estado, en cualquiera de los órganos que ejerce actividad jurisdiccional, está obligado a respetar el principio de separación de poderes o distribución de funciones, que garantiza la existencia de un juez natural que sea independiente.

Asimismo, y de manera especial, tratándose de autoridades judiciales, deben ejercer sus funciones con independencia, ajenos a presiones que puedan provenir de otros órganos de poder, tal como entendió el TEDH cuando considera que el Estado debe cumplir con la separación de poderes, mirando a los límites de interacción de poderes, debiéndose dar una separación entre los órganos políticos de gobierno y los judiciales ${ }^{55}$. Y es que la independencia «no es un privilegio personal del juez es, sobre todo, una independencia funcional dentro del proceso, y actúa frente a otros órganos judiciales y frente a los demás poderes» ${ }^{56}$, pues «un Estado en donde los jueces sufran coacción de los gobernantes, legisladores y políticos, deja de ser un Estado de Derecho ${ }^{57}$, perdiendo la administración de justicia una de sus mayores garantías, que es la independencia.

En cuanto a los mecanismos que aseguran la independencia del juzgador, el TEDH en 1984, estableció los criterios necesarios para asegurarla. Están referidos al tipo de nombramiento y duración del mandato, la existencia de garantía contra presiones externas (inamovilidad) y si el órgano presenta una apariencia de independencia ${ }^{58}$; ese razonamiento ha sido

${ }^{53}$ Párrafo 71.

${ }^{54}$ Ibidem.

55 Caso Stafford Vs. Reino Unido, Sentencia de 28 de mayo de 2002; Caso Sacilor Lorminess Vs. Francia, Sentencia de 09 de noviembre de 2006.

56 Javier García Roca y José Miguel Vidal Zapatero, El derecho ..., 367.

57 Hernando Devis Echandía, Teoría general del Proceso, (Buenos Aires-Argentina: Universidad S.R.L., 1997), 129.

${ }^{58}$ Caso Campbell y Fell Vs. Reino Unido, Sentencia de 28 de junio de 1984. 
asumido de manera expresa por la CIDH en 2001 cuando considera que: «la independencia de cualquier juez supone que se cuente con un adecuado proceso de nombramiento, con una duración establecida en el cargo y con una garantía contra presiones externas $\rangle^{59}$, aunque ya no hace mención al último mecanismo, relativo a determinar si el órgano presenta o no una apariencia de independencia.

El primer mecanismo referido al nombramiento de autoridades jurisdiccionales judiciales, de manera general se realiza por el órgano legislativo, forma de designación que ha creado cierta susceptibilidad, que ha motivado cambios hasta realizarse por elección popular, lo que ha provocado el riesgo de la politización; en todo caso, sea cual fuere la forma de designación, es necesario demostrar que la forma de nombramiento es: «insatisfactoria como un todo ... (o que) al menos el establecimiento de un Tribunal concreto fue influenciado por motivos impropios $\rangle^{60}$.

El TEDH en 1998 ya consideró que el nombramiento de Presidentes de ciertos órganos administrativos con potestad sancionadora se hacía bajo el control del Gobierno ${ }^{61}$, en cuyo caso, mal puede un nombramiento de ese tipo asegurar la independencia de un juzgador. La CIDH, asumiendo específicamente razonamientos del TEDH, ratificó su posición en sentido de que la independencia de cualquier juez supone que se cuente con un adecuado proceso de nombramiento ${ }^{62}$.

Hay que tener en cuenta que en el sistema de nombramiento de las autoridades judiciales en particular, y de las jurisdiccionales en general, o de todos los que ejercen función jurisdiccional, debería garantizar su independencia, siendo «indispensable un procedimiento eficaz en los nombramientos de los funcionarios ... Es en la forma de designarlos y en su calidad, no en la vigilancia y castigo, donde se encuentra la garantía de una justicia independiente». Un elemento fundamental para el fortalecimiento de un Estado de Derecho, es la garantía de la independencia de jueces y tribunales, que solo se logra a través de un adecuado mecanismo de selección y designación de autoridades jurisdiccionales, sean judiciales o no.

Esta garantía de la independencia, tiene una estrecha relación con otra que es de la imparcialidad, así se dijo que «una línea de nombramientos interferidos políticamente, no se dará sin consecuencias en el plano de la imparcialidad, en particular, cuando se trate de juicios de relevancia política», es que la independencia e imparcialidad están estrechamente relacionados

${ }^{59}$ Caso Tribunal Constitucional Vs. Perú, Sentencia de 31 de enero de 2001, párr. 75.

${ }^{60}$ Zand Vs. Austria, Informe de la Comisión de 12 de octubre de 1978.

${ }^{61}$ Caso Kudabec Vs. Eslovaquia, Sentencia de 02 de septiembre de 1998.

${ }^{62}$ En el referido Caso Tribunal Constitucional Vs. Perú, Sentencia de 31 de enero de 2001, párr. 75 ya citado. 
aunque no son lo mismo, la independencia es un presupuesto político y orgánico de la imparcialidad (que se estudiará con posterioridad), en todo caso un juez o tribunal no condicionado políticamente (independiente), podría al mismo tiempo no estar en posición de equidistancia con relación a las partes o al objeto del juicio mismo (parcial).

Se encuentra estrechamente relacionado a la forma de nombramiento y/o designación, el otro mecanismo referido a «si el órgano presenta una apariencia de independencia», que se entiende mejor a través de la casuística, por ejemplo, cuando un Consejo Policial con función jurisdiccional está integrado por una persona que prestó juramento al resto de los policías, está subordinado a sus superiores y leal a sus colegas, situación que «podía legítimamente plantear dudas sobre la independencia e imparcialidad organizativa del Consejo Policial» por tanto lesiona el art. 6.1 del CEDH, como entendió en 1988 el TEDH ${ }^{63}$. En esa línea otros casos, cuando se conoció y resolvió asuntos relativos al sistema británico de la justicia militar, entre ellos en 1997, en el Caso Findlay contra el Reino Unido, en el cual el TEDH refiriéndose a la figura del convening officer, relativo a la acusación, señaló que la desconfianza del acusado y demandante acerca de la independencia del Tribunal penal militar estaban suficientemente fundadas, por el papel clave en la acusación y al mismo tiempo designación a los miembros de la corte marcial, quienes eran inferiores en rango a él y caían dentro de su cadena de mando ${ }^{64}$.

El mecanismo referido a la apariencia de independencia (vinculado al nombramiento), si bien no fue asumido de manera expresa por la $\mathrm{CIDH}$, lo ha sido implícitamente, cuando reconoció, por ejemplo, que jueces y tribunales militares no presentan una apariencia de independencia. Muchos son los pronunciamientos en ese sentido, tal el Caso de 1999, denominado Castillo Petruzzi, en el que se manifestó que: «el nombramiento de los miembros del Consejo Supremo de Justicia Militar, máximo órgano de la jurisdicción castrense, es realizado por el Ministro del sector pertinente. Los miembros del Consejo Supremo Militar son quienes, a su vez, determinan los futuros ascensos, incentivos profesionales y asignación de funciones a sus inferiores. Esta constatación, pone en duda la independencia de los jueces militares $\rangle^{65}$; resulta cuestionable y hace dudar la independencia de los tribunales

${ }^{63}$ Caso Belilos Vs. Suiza, Sentencia de 28 de abril de 1988.

${ }^{64}$ Caso señalado, Sentencia de 25 de febrero de 1997; en similares situaciones los casos Coine contra reino Unido, de 24 de septiembre de 1997, Cable y otros contra Reino Unido, de 18 de febrero de 1999, Wilkinson y Allen contra Reino Unido, de 06 de febrero de 2001.

${ }^{65}$ Párrafo 130. 
militares, cuando los mismos son designados por el Ministro del ramo, que forma parte del Órgano Ejecutivo.

Asimismo en el Caso Palamara Iribarne Vs. Chile de 2005, se indicó que: «La Corte estima que ... tribunales militares ... su nombramiento no depende de su competencia profesional e idoneidad para ejercer las funciones judiciales ... no posean una formación jurídica exigible para desempeñar el cargo de juez o fiscales. Todo ello conlleva a que dichos tribunales carezcan de independencia e imparcialidad $\rangle^{66}$.

La CIDH, sin así decirlo, asume la posición que ya tuvo el Tribunal Europeo, cuestionándose en ambos tribunales la independencia del tribunal penal militar, por el origen o la forma de designación, dudándose de la independencia del juzgador.

Entre los mecanismos que aseguran la independencia del juzgador, además del nombramiento y de la apariencia de independencia -a las que se acaba de hacer referencia-, está la duración del mandato y la existencia de garantías contra presiones externas (inamovilidad), como reconoció el TEDH. Las últimas están referidas al hecho de que cuando una autoridad jurisdiccional ha sido adecuadamente nombrada, no debe ser removida de su cargo durante todo su mandato -salvo que existan causas legalmente previstas-, debiendo estar asegurada su inamovilidad, como garantía de su independencia o contra presiones externas.

La inseparabilidad de un miembro de un tribunal, durante el tiempo de su mandato, no precisa un «reconocimiento jurídico formal», como entendió el TEDH en 1984, cuando además considero suficiente que fuera «reconocida de hecho y que las otras garantías estuvieran presentes». Así se tiene que las autoridades jurisdiccionales de carrera, gozan de inamovilidad durante todo el tiempo de su mandato, como reconoció la Comisión IDH en 1997, salvo que sean destituidos de su cargo, mediando el ejercicio del derecho a la defensa, dentro de un debido proceso, como se entiende de señalado por la CIDH el 2001.

\subsection{Juez imparcial}

La independencia y la imparcialidad, se constituyen en dos principios básicos de la administración de justicia, distintos pero complementarios, así: «un juez imparcial requiere ... ser independiente ... mientras que un juez puede ser independiente y, sin embargo no ser imparcial a la hora de conocer una causa determinada» ${ }^{67}$.

${ }^{66}$ Párrafo 155.

${ }^{67}$ Rafael JimÉnEz AsEnsio, Imparcialidad judicial y derecho al juez imparcial, (Navarra: Ed. Aranzadi S.A., 2002), 71. 
No es suficiente que un Juez o Tribunal a tiempo de resolver una causa actúe de manera independiente ${ }^{68}$, sino que es necesario que el mismo sea imparcial y que la única razón que lo guíe sea la correcta administración de justicia, sin desviar sus apreciaciones a ningún tipo de consideración: sea de amistad, enemistad, simpatías o antipatías, razones políticas, religiosas u otras, lucro personal o dádivas ilícitamente ofrecidas y obtenidas, etc.

La imparcialidad supone que el tribunal o juez no tiene opiniones preconcebidas sobre el caso sub judice ${ }^{69}$, es decir que a tiempo de conocer y resolver una causa, sus apreciaciones no son parciales, sesgadas, ni cargadas de prejuicios con relación a ninguno de los sujetos procesales. Por eso se manifestó que la imparcialidad es una: «actitud, que nos muestra que este juzgada sin interferencias ni concesiones arbitrarias a una parte $»^{70}$,

La doctrina de la imparcialidad del juez natural, ha sido desarrollada por el TEDH, recogida de manera expresa por la CIDH, en el caso Apitz Barbera y otros Vs. Venezuela, en Sentencia 5 de agosto de 2008, que señaló que esa imparcialidad se compone de elementos subjetivo y objetivo. eE el primer caso, «exige que el juez que interviene en una contienda particular se aproxime a los hechos de la causa careciendo, de manera subjetiva, de todo prejuicio», a su vez el segundo caso implica que un juzgador debe participar en una contienda judicial: «ofreciendo garantías suficientes de índole objetiva que permitan desterrar toda duda que el justiciable o la comunidad puedan albergar respecto de la ausencia de imparcialidad».

De acuerdo a esa doctrina, el aspecto subjetivo de la imparcialidad está en relación con la convicción personal del juez en un determinado caso, sometido a una presunción iuris tantum; es decir, que se presume la imparcialidad del juzgador, salvo prueba en contrario; imparcialidad que se: «origina por la relación extraprocesal que cualquiera (o todos) los miembros del órgano juzgador tenga o haya tenido con las partes en el proceso».

A su vez, el aspecto objetivo de la imparcialidad se refiere a la falta de contacto anterior por parte de los magistrados con el thema dedidendi, que pueda haberles causado un perjuicio a alguna de las partes; lo que implica que la imparcialidad objetiva deriva de la relación o contacto que el órgano judicial haya podido tener con los hechos y con alguna de las partes con anterioridad a la sustanciación del proceso.

${ }_{68}$ Actuación independiente que se dará cuando la autoridad jurisdiccional sea autónoma, sometida única y exclusivamente a la Constitución y las leyes, no así al poder de cualquier otro órgano del Estado, en el marco del principio de separación de funciones, que se constituye la base del sistema democrático.

${ }^{69} \mathrm{CIDH}$ Informe n. ${ }^{\circ}$ 78/02 de 27 de diciembre, en el Caso 11.335, Guy Malary Vs. Haití, párrafo 74.

70 Rafael JimÉnEZ AsEnsio, Imparcialidad ..., 71. 
La imparcialidad subjetiva (personal) u objetiva (funcional), está relacionada a la percepción razonable de imparcialidad que pueda tener el que será juzgado, excluyéndose cualquier duda legítima de parcialidad del juez, sobre la base de elementos perceptibles (subjetiva u objetivamente, según el caso) que permitan establecer que el juzgador no está siendo sometido a ningún tipo de influencia, prejuicio o intromisión, sino motivado únicamente por el interés de lograr una correcta administración de justicia.

Dentro de las ideas-fuerza de la interpretación del concepto de imparcialidad realizado por el TEDH, está la apariencia de un juzgador imparcial, que debe valorarse en favor de la confianza que tienen los justiciables, en los órganos de administración de justicia ${ }^{71}$.

El TEDH en 1970, considero el adagio: «'justice must not only be done, it must also be seen to be done' (no solo debe hacerse justicia, sino advertirse que se hace), estas consideraciones permitirán albergar algunas dudas sobre la naturaleza satisfactoria o no del sistema en cuestión $\rangle^{72}$; en ese sentido en la Sentencia Piersack de 1982, consideró que la imparcialidad descansa en la confianza que deben inspirar los tribunales a los ciudadanos; y en el mismo sentido la Sentencia De Cubber de 1984, en la que también expresó que: «debe recusarse todo juicio del que se pueda legítimamente temer una falta de imparcialidad ... esto se deriva de la confianza que los Tribunales de una sociedad democrática deben inspirar a los justiciables».

Aplicando esos criterios se establece la desconfianza que tienen el acusado como el demandante, con relación a la independencia e imparcialidad de un tribunal penal militar, que tiene un papel de acusación, pero al mismo tiempo designa a los miembros de una corte marcial, que son inferiores en rango y caen dentro de una cadena de mando; en ese sentido se analizó en muchos casos en el TEDH ${ }^{73}$.

Dichas interpretaciones, han sido asumidas de manera genérica por la $\mathrm{CIDH}$ en diversos casos, en los que consideró que miembros de tribunales militares, generan desconfianza o no satisfacen los requerimientos de independencia e imparcialidad, al ser parte y juzgar, al ser parte de fuerzas en servicio, al combatir y juzgar y otros; así se reconoció en diversos fallos de 1999, 2000, 2001y otros ${ }^{74}$.

${ }^{71}$ Como entiende Rafael Jimenez Asensio, citado por Javier García Roca y José Miguel DíAz ZAPATERO, El derecho..., 378 y 382.

72 Caso Delcourt Vs. Bélgica, Sentencia de 17 de enero de 1970.

${ }^{73}$ Caso Fidlay Vs. Reino Unido, sentencia de 25 de febrero de 1997; Caso Cooper Vs. Reino Unido, sentencia de 16 de diciembre de 2003, Miller y otros contra el Reino Unido, de 26 de octubre de 2004, entre otros.

${ }^{74}$ Caso Castillo Petruzzi Vs. Perú, Sentencia de 30 de mayo de 1999, párr. 130; Caso Durand y Ugarte Vs. Perú, Sentencia de 26 de agosto de 2000, párr. 126; Caso Cantoral 


\section{DIÁLOGO ENTRE EL TEDH Y EL TRIBUNAL CONSTITUCIONAL ESPAÑOL}

El elemento imparcialidad del juez natural, garantiza la existencia de una justicia imparcial, por ello: «La imparcialidad es consustancial a la propia función de juzgar: un Juez parcial no es un verdadero Juez» ${ }^{75}$. Señala al respecto el Tribunal Constitucional en la STC 133/2014, de 22 de julio de 2014, que «constituye una garantía fundamental de la Administración de Justicia en un Estado de Derecho que condiciona su existencia misma, ya que sin Juez imparcial no hay, propiamente, proceso jurisdiccional.».

Ha sido el TEDH quién en 1982 en el Caso Piersack ha configurado, el derecho a un juez imparcial, partiendo del reconocimiento de que la imparcialidad se define por la ausencia de prejuicios o parcialidades, contando con dos dimensiones, pudiéndose así distinguir entre: «un aspecto subjetivo, que trata de averiguar la convicción personal de un Juez determinado en un caso concreto (que debía ser presumida mientras no se demuestre lo contrario), y un aspecto objetivo, que se refiere a si éste ofrece las garantías suficientes para excluir cualquier duda razonable al respecto» ${ }^{76}$. En esa virtud se tiene que por esa doble dimensión, la imparcialidad puede apreciarse de modo subjetivo, apreciación que es difícil que tenga éxito, porque requiere la prueba de un factor interno o espiritual, como es un determinado prejuicio del juzgador respecto al caso; en cambio la otra dimensión objetiva, tiene más posibilidades de ser probada, porque puede apreciarse la imparcialidad, prescindiendo de la subjetividad del juez para el caso concreto ${ }^{77}$.

Esta doctrina se va consolidando en 1984 en el Caso De Cubber, cuando el TEDH, reitera la doble dimensión de la imparcialidad, concluyendo que se ha lesionado la imparcialidad objetiva, comprendiéndose que: «un inculpado pueda inquietarse si encuentra, en el seno del Tribunal llamado a decidir sobre la fundamentación de la acusación, al Magistrado que le había puesto en situación de detención preventiva y le había interrogado durante la instrucción preparatoria» ${ }^{78}$; hay que recordar que la instrucción en el proceso penal belga, es una de tipo inquisitivo, de ahí que el ejercicio sucesivo de las funciones de instrucción y enjuiciamiento por un mismo juez, contamina su imparcialidad,

Benavides Vs. Perú, Sentencia de 18 de agosto de 2000, párr. 114; Caso Las Palmeras Vs. Colombia, Sentencia de 06 de diciembre de 2001, párr. 53.

75 Ignacio DE OTTO, Estudios sobre el Poder Judicial, (Madrid: Ministerio de Justicia, 1989), 23.

${ }^{76}$ Caso Piersack Vs. Bélgica, Sentencia de 1ro. de octubre de 1982.

77 Como señala Ortells RAmos, citado por Alexandre CATAlÀ I BAS, «Libertad de expresión e información. La jurisprudencia del TEDH y su recepción por el Tribunal Constitucional», Revista General de Derecho, (2001): 396.

${ }^{78}$ Caso Cubber Vs. Bélgica, Sentencia de 26 de octubre de 1984. 
al poderse formar prejuicios del acusado cuando se celebra el juicio, sobre la base de la culpabilidad del imputado durante la fase de la instrucción.

En el contexto europeo, el Tribunal Constitucional de España, asumió de manera expresa y específica, la doctrina de la doble dimensión de la imparcialidad, cuando emitió la STC 145/1988, de 12 de julio, en la que basándose en la jurisprudencia de los casos Piersack y De Cubber, se ha declarado inconstitucional el art. 2 de la Ley Orgánica 10/1980, que consideraba que el juez que instruía podía también resolver, por ser contraria al derecho al juez imparcial. Asimismo, en la STC 162/1999, de 27 de septiembre, se asumió específicamente la doble dimensión desarrollada por el TEDH, cuando consideró que:

«El método de apreciación de estas exigencias empleado por el T.E.D.H., cuya jurisprudencia constituye un obligado y valioso medio hermenéutico para configurar el contenido y alcance de los derechos fundamentales (art. 10.2 C.E.), se caracteriza por distinguir dos perspectivas -subjetiva y objetiva-, desde las que valorar si el Juez de un caso concreto puede ser considerado imparcial [Sentencias del T.E.D.H. dictadas en los casos Piersack (§30) y De Cubber ( 24 ), antes citados, a cuya doctrina se remiten las posteriores]. La perspectiva subjetiva trata de apreciar la convicción personal del Juez, lo que pensaba en su fuero interno en tal ocasión, a fin de excluir a aquel que internamente haya tomado partido previamente, o vaya a basar su decisión en prejuicios indebidamente adquiridos. Desde esta perspectiva, la imparcialidad del Juez ha de presumirse, y las sospechas sobre su idoneidad han de ser probadas. La perspectiva objetiva, sin embargo, se dirige a determinar si, pese a no haber exteriorizado convicción personal alguna ni toma de partido previa, el Juez ofrece garantías suficientes para excluir toda duda legítima al respecto (caso Hauschildt, $\S$ 48); por ello, desde este punto de vista, son muy importantes las consideraciones de carácter funcional y orgánico, pues determinan si, por las funciones que se le asignan en el proceso, el Juez puede ser visto como un tercero en el litigio, ajeno a los intereses que en él se ventilan.».

Posteriormente, siguiendo la doble dimensión de la imparcialidad, el Tribunal Constitucional Español va sentando significativas diferencias, cuando considera que la vertiente subjetiva de la imparcialidad atiende a las relaciones del juez con las partes en litigio y la vertiente objetiva con el thema decidendi, tal lo expresado en STC 85/2003, de 08 de mayo, igual que en STC $52 / 2001$, de 26 de febrero. Es decir que mientras en el TEDH la imparcialidad subjetiva se sitúa en lo que piensa el juez o su fuero interno, en la doctrina que va creando el TC la imparcialidad afecta a las sospechas que puede existir en las relaciones del juez con las partes; a su vez, la imparcialidad objetiva del TEDH valora que el juez ofrezca o no las garantías para excluir toda duda legítima, en la doctrina del TC la imparcialidad afecta a la relación del juez con el objeto del proceso. De ahí se manifestó que: «puede que la matización efectuada por el Tribunal Constitucional español acaso fuera más eficaz en la 
práctica $\rangle^{79}$, porque la imparcialidad deriva de la relación o de los vínculos que pueda tener el juez, sea con las partes o con el objeto del proceso.

A pesar de ello, cabe advertir que la recepción de la jurisprudencia del TEDH por parte del Tribunal Constitucional en esta cuestión es muy notable. Valga de ejemplo la sentencia 133/2014, que, en el fundamento jurídico 3, transcribe de forma literal los párrafos 93 a 98 de la STEDH Micallef c. Malta, de 15 de octubre, que, con numerosas referencias a sentencias del propio Tribunal, sistematiza toda su jurisprudencia sobre el tema. Se habla así de valoración subjetiva en el sentido de ausencia de prejuicios o parcialidad, existiendo una presunción de imparcialidad en favor del tribunal; de valoración objetiva que asegura que el tribunal en si mismo, y, entre otros aspectos, su composición, vínculos jerárquicos o de otro tipo entre las jueces y los actores en el procedimiento, doble papel del juez, etc., ofrece suficientes garantías para excluir cualquier duda legítima con respecto a la imparcialidad. También hay que tener en cuenta cuestiones de organización interna como la existencia de mecanismos para asegurar la imparcialidad como normas que regulen la recusación de los jueces. Tras ello reconoce el Tribunal Constitucional que «a esta distinción ha atendido también este Tribunal», exponiendo, eso sí, las diferencias sobre qué hay que entender por imparcialidad manifestadas supra.

\section{DIÁLOGO ENTRE LA CIDH Y TRIBUNALES CONSTITUCIONALES AMERICANOS (BOLIVIA, COLOMBIA Y PERÚ)}

En este epígrafe se analiza la comunicación entre la CIDH y los Tribunales Constitucionales de Bolivia, Perú y Colombia. Ello no obstante, se hará referencia en más de una ocasión a sentencias del TEDH con el objeto de mostrar la coexistencia de un dialogo horizontal entre los dos órganos supranacionales y de uno vertical entre la Corte y los órganos estatales. Es decir, como la jurisprudencia del TEDH es asumida por la Corte y, normalmente, a través de ella, por los tribunales estatales. Si con anterioridad hemos mostrado la influencia de la jurisprudencia del TEDH en el Tribunal Constitucional, se ve claramente como se produce una armonización intra y extra sistemas, creador de un estándar común a nivel europeo y americano.

\subsection{Juez competente}

La CIDH, en Sentencia de 30 de mayo de 1999 en el Caso Castillo Petruzzi y otros Vs. Perú, con relación a la competencia legal del juez natural

79 Javier García de la Roca y José Miguel Vidal ZAPATERo, El derecho..., 380. 
señaló: «toda persona tiene derecho a ser juzgada por tribunales de justicia ordinarios con arreglo a procedimientos legalmente establecidos $\left.{ }^{80}\right\rangle$; es decir que los jueces y tribunales deben juzgar con arreglo a una ley previamente establecida, no por jueces ni tribunales ad-hoc.

En el mismo sentido ya se pronunció el TEDH cuando en 1988, al referirse a un Tribunal que cumple función judicial, señaló que es aquel que debe: «resolver asuntos dentro de su competencia sobre la base de reglas jurídicas y conforme a procedimientos con conducidos de manera preestablecida $\rangle^{81}$, en la misma sentencia también se señaló que el tribunal debe cumplir con una serie de requerimientos, como es la independencia e imparcialidad.

Lo dicho por el TEDH, como lo señalado por la CIDH, ha sido asimilado por Tribunales estatales americanos, así Tribunales estatales como el Tribunal Constitucional de Bolivia, en ese mismo sentido, realiza interpretaciones sobre el alcance del juez competente, que es el llamado a resolver controversias de acuerdos a reglas establecidas por ley, efectuando referencias genéricas a fallos de la CIDH, en algunos casos la menciones son específicas (Tribunal Constitucional Vs. Perú) y, en otros casos las remisiones son a otras sentencias del TC, que a su vez hacen referencia específica a fallos interamericanos.

El artículo 8.1 de la Convención al garantizar el derecho a ser juzgado por un tribunal competente, hace mención a que el mismo deberá ser: «... establecido con anterioridad a la ley», siendo necesario fijar el alcance de esa regulación normativa.

El derecho a ser juzgado por un juez natural con una competencia establecida con anterioridad por la ley, ha sido también reconocido por los países de la región andina, así el art. 139.3 de la Constitución Política del Perú, Y el párrafo II del art. 29 de la Constitución Política de la República de Colombia. Por su parte, El art. 120-I de la Constitución Política del Estado Plurinacional de Bolivia, regula el derecho al juez natural, pero no se refiere de manera expresa a una ley anterior o una ley preexistente o previamente determinada, sino que menciona la existencia de autoridades que deben ser establecidas con anterioridad al hecho de la causa.

Si un asunto está siendo juzgado, tendrá que ser con jueces o tribunales cuya competencia haya estado establecida con carácter previo por la ley, con relación a criterios objetivos como: materia, cuantía, territorio, entre otros; pues caso contrario, se vulnera el derecho al juez natural y competente, como entendió la CIDH en el Caso Ivcher Bronstein Vs. Perú, en Sentencia de 06 de febrero de 2001,cuando señaló que: «La Corte considera que el Estado, al crear Salas y Juzgados ... y designar jueces que integraran los mismos, en el

\footnotetext{
80 Párrafo 129.

${ }^{81}$ Caso Belilos contra Suiza, Sentencia de 29 de abril de 1988.
} 
momento en que ocurrían los hechos del caso sub judice, no garantizó ... el derecho a ser oído por jueces o tribunales establecidos «con anterioridad por la ley», consagrado en el artículo 8.1 de la Convención Americana» ${ }^{82}$; es que en ningún caso una persona puede ser juzgada con jueces que para el efecto o para ese juzgamiento se designaron, esa situación irregular implicaría la existencia de un juez o tribunal ad-hoc, un fuero especial y violación del derecho al juez natural con competencia previamente establecida por la ley.

Precisamente la CIDH, en el Caso Castillo Petruzzi y otros Vs. Perú citado así como en Sentencia de 05 de agosto de 2008 emitida en el Caso Apitz Barbera y otros vs. Venezuela, señaló que la finalidad o el objetivo que se persigue con el juzgamiento por un tribunal competente establecido por ley anterior, es garantizar el derecho a ser juzgado por un tribunal competente, con lo que: «se busca evitar que las personas sean juzgadas por tribunales especiales, creados para el caso, o ad hoc.. ${ }^{83}$.

Vinculadas a estas interpretaciones, se tienen otras como las que desarrolló la CIDH, en el Caso Cesti Hurtado Vs. Perú, cuando emitió la Sentencia de 29 de septiembre de 1999, en la que manifestó que: «el juicio constituye una violación al derecho a ser oído por un tribunal competente, de acuerdo con el artículo 8.1 de la Convención $»^{84}$, por lo que «el fuero militar es incompatible con la Convención $\rangle^{85}$. Es decir, cualquier fuero militar o especial, es violatorio al derecho a un juez competente (fueros militares incompatibles con el derecho a un juez competente). El reconocimiento de un fuero especial militar, que vulnera el derecho al juez natural, ha sido un razonamiento reiterado en la Corte, así el 2000 en el Caso Cantoral Benavides Vs. Perú, cuando señaló: «este fuero ... supone excluir al juez natural para el conocimiento de estas causas ${ }^{86} \gg$, entre otros.

En esa virtud se tiene que, primero es la ley la que establece la competencia de la autoridad jurisdiccional, sobre esa base se juzga; con esto se tiende asegurar que los procesos sean tramitados y resueltos por autoridades con potestad jurisdiccional y competencia, no así por jueces o tribunales ad-hoc que son diferentes a los que de manera regular juzgan, creados intencionadamente para resolver un determinado caso, donde indudablemente no habrá más que una grave violación al derecho al juez natural.

Con relación al derecho a un juez con competencia previamente establecida, dada para evitar juzgamientos con jueces o tribunales constituidos para casos concretos, que vienen a ser de carácter $a d-h o c$, violatorios al derecho al

\footnotetext{
${ }^{82}$ Párrafo 115.

83 Párrafo 50.

84 Párrafo 151.

85 Párrafo 194.

${ }^{86}$ Párrafo 112.
} 
juez natural competente, la Corte Constitucional de Colombia realizó ciertas apreciaciones.

Sobre la base de la doctrina desarrollada por dicha Corte Constitucional, relativa a que la violación del derecho a no ser juzgado por tribunales constituidos con ocasión de una determinada conducta o conocida como «la fijación ex post facto de competencias», en la tramitación de una acción de tutela (amparo constitucional), se ha pronunció la Sentencia T-058/06 de 02 de febrero de 2006, en la que asumiendo de manera expresa criterios generales de la CIDH (del Caso Tribunal Constitucional Vs. Perú), señaló que es una vía de hecho el desconocimiento del derecho a ser juzgado ante juez o tribunal competente, estando: "proscrita como lo está la fijación ex post facto de competencias judiciales ... como también su señalamiento ad hoc por parte de autoridades administrativas o judiciales .... ${ }^{87}$; en la misma Sentencia se indicó que: «la esencialidad del mismo (del derecho a un juez natural competente), centrada en que no se establezcan «jueces o tribunales $a d-h o c »{ }^{88}$.

Es que es propio del derecho a un juez natural competente, que con carácter previo al conocimiento y tramitación de una causa, se defina quienes son los jueces competentes y que sean ellos y no un tribunal ad-hoc que conozca y resuelva los casos litigiosos.

Con referencia al hecho de que los procesos sean resueltos por autoridades con competencia previamente determinada por ley, de acuerdo a diversos criterios objetivos como: materia, cuantía, territorio, entre otros, debe tenerse en cuenta el desarrollo jurisprudencial que al respeto desarrolló el Tribunal Constitucional de Bolivia.

En SC 1364/2002-R de 7 de noviembre, el Tribunal Constitucional de Bolivia, señaló que el derecho a un juez natural tiene un doble alcance, así: «en criterio de la CIDH tiene dos alcances: a) la imposibilidad de ser sometido a un proceso ante la autoridad de quien no es juez o que carece de competencia para resolver determinada causa $\rangle^{89}$, refiriéndose a ese primer criterio señaló que: «la misma Corte ... entendió que se considera un tribunal competente al que es llamado a conocer y resolver una controversia de acuerdo a determinadas reglas preestablecidas ya sea de territorio, materia u otros elementos $\rangle^{90}$, el alcance del segundo criterio sería el: «b) que la competencia de los jueces y tribunales se encuentre previamente establecida por ley» ${ }^{91}$.

Es necesario hacer notar, que lamentablemente esa Sentencia adolece de una imprecisión, pues con relación al alcance del derecho juez natural se

\footnotetext{
${ }^{87}$ Punto 4.1.

${ }^{88}$ Ibidem.

89 Punto III.1 de Fundamentos.

${ }^{90}$ Punto III.2 de Fundamentos.

91 Punto III.1 de Fundamentos.
} 
refiere a los criterios que habría establecido la CIDH, pero no señala en qué casos se hubieran fijado los mismo, si en una Sentencia o en una Opinión Consultiva, lo que deja en duda cuál es el origen preciso de los razonamientos de esa decisión ${ }^{92}$. No es un fenómeno extraño. Así los autores han distinguido entre una referencia expresa y otra tácita o implícita ${ }^{93}$.

El mismo Tribunal Constitucional de Bolivia en SC 0491/2003-R de 15 de abril de 2003, se ha referido de manera muy general, al derecho al juez natural competente, además de independiente e imparcial, como parte de un debido proceso, señalando: «Uno de los elementos esenciales de la garantía del debido proceso es el derecho al juez natural competente, independiente e imparcial», remitiéndose a lo señalado por: «la Corte Interamericana de Derechos Humanos, cuya jurisprudencia es vinculante para la jurisdicción interna, en su Sentencia de 31 de enero de 2001 (Caso Tribunal Constitucional del Perú, párrafo 77) $\rangle^{94}$. Esta Sentencia tiene la virtud de establecer de manera expresa el carácter vinculante de la jurisdicción internacional de la $\mathrm{CIDH}$, con relación a la jurisdicción constitucional del Estado de Bolivia; además los razonamientos en ella contenidos, han sido reiterados en innumerables casos ${ }^{95}$.

El mismo Tribunal Constitucional de Bolivia, en SC 0074/2005 de 10 de octubre, realizó un interesante desarrollo sobre las condiciones que deben darse para que exista un juez predeterminado, con competencia previamente establecida en la ley, tal que el órgano judicial: «i) haya sido creado previamente por un precepto legal; ii) ... esté investido de jurisdicción y competencia con anterioridad al hecho motivador del proceso ...; iii) ... no permita calificarlo de tribunal ad hoc o de comisión especial; iv) la composición ... venga determinada por la ley; y v) ... se siga el procedimiento ... para la designación de ... el órgano respectivo» ${ }^{96}$.

${ }_{92}$ Los criterios señalados, que se dice habrían partido de la Corte Interamericana ( $₫$ ?), han sido reiterado en la SC 004/2003 que se emitió en la tramitación de un Recurso Directo de Nulidad, Sentencia que en las partes transcritas (relativas al criterio de la Corte en cuanto al alcance del juez natural), han sido repetidos en las SC 0093/2005-R, SC 0060/2005 RDI, SC 1581/2005-R, que equivocadamente asumen el razonamiento de la segunda (SC 004/2003) y no así la primera (SC 1364/2002-R), que fue en realidad la sentencia hito en el tema señalado.

93 Vide Alexandre H. CATALÀ I BAS, «Libertad de expresión e información. La jurisprudencia del TEDH y su recepción por el Tribunal Constitucional», Revista General de Derecho, (2001): 419 y García Roca, Javier, Nogueira Alcalá, Humberto y Bustos GISBERT, Rafael, La comunicación entre ambos sistemas..., 85, y Rodrigo BRITo MELGAREJO, «El uso de sentencias extraneras en los Tribunales Constitucionales. Un análisis comparativo», InDret, (2/2002), 19.

${ }_{94}$ Punto III.2. de Fundamentos.

95 Tal en: SC 1148/2003-R, SC 1730/2003-R, SC 0009/2004, SC 0664/2004-R, SC 0430/2005-R, SC 0731/2005-R, entre otros.

${ }^{96}$ Punto III.3.a. de Fundamentos. 
Todos estos razonamientos han sido asumidos, dirá el Tribunal Constitucional de Bolivia, «siguiendo ... la amplia jurisprudencia emanada de la Corte Interamericana de Derechos Humanos $\rangle^{97}$. Deben tenerse en cuenta dos consideraciones; por una parte, nuevamente este Tribunal vuelve a caer en una imprecisión similar a la antes mencionada, en cuanto no aclara si el razonamiento de la CIDH (referido a las condiciones), provienen de una Sentencia o de una Opinión Consultiva, menos se señala la fecha o algún otro dato que permita identificar ese razonamiento; por otra parte, cabe resaltar el desarrollo realizado, que en cinco puntos condensa el alcance (aunque venga con la denominación de condiciones) del derecho a ser sentenciado por un juez con competencia previamente establecida en la ley.

La finalidad de la existencia del establecimiento de una ley anterior, que asegure un juez competente, también ha sido señalada por el Tribunal Constitucional de Bolivia, en SC n. ${ }^{\circ}$ 560/2002-R de 15 de mayo, cuando manifestó que el derecho al juez natural: «tiende a evitar la sustitución implantación de órganos jurisdiccionales distintos a los que de manera regular tienen establecida su competencia para conocer el asunto en cuestión».

Dicho establecimiento de un juez competente con anterioridad por la ley, conlleva un criterio de tipo temporal (de anterioridad), que a veces ha sido confundido con otro criterio temporal (de posterioridad), que se da con relación al juez designado de manera ulterior al hecho que se juzga sobre la base de la ley; última posibilidad que por prohibición constitucional en Bolivia parecería no estar permitida, cuando se señala que nadie: «podrá ser ... sometida a otras autoridades jurisdiccionales que las establecidas con anterioridad al hecho de la causa $\rangle^{98}$.

La acción de amparo constitucional que dio lugar a la referida SC n. ${ }^{\circ}$ 560/2002-R, tiene como base una demanda en la que el accionante denunció la violación de su derecho al juez natural, porque la autoridad judicial que tomó conocimiento de su causa, era un juez designado con posterioridad (no con anterioridad) al hecho que motivó su proceso penal; el Tribunal Constitucional, a tiempo de denegar la acción planteada ${ }^{99}$, entendió «que los alcances del precepto constitucional (art. $14^{100}$ ) no pueden extraerse de la literalidad

\section{Ibidem.}

${ }_{98} \mathrm{El}$ art. 120-I de la CPE de Bolivia, establece que: «Toda persona tiene derecho a ser oída por una autoridad jurisdiccional competente, independiente e imparcial, y no podrá ser juzgada por comisiones especiales ni sometida a otras autoridades jurisdiccionales que las establecidas con anterioridad al hecho de la causa».

99 Establecido en el art. 14 de la Constitución Política del Estado de 1967, reformada en 2004 y abrogada por la Constitución Política del Estado Plurinacional de febrero de 2009, que en el mismo sentido reguló en el indicado art. 120-I de la CPE.

100 Ahora art. 120-I de la CPE. 
del precepto, sino de la finalidad que el mismo tiene dentro del orden constitucional», De ahí que, de manera congruente con lo anotado, cuando dicho precepto dice «Nadie debe ser juzgado por comisiones especiales o sometido a otros jueces que los designados con anterioridad al hecho de la causa», está desarrollando la garantía del Juez natural, dentro de los alcances anteriormente expuestos, y no a prohibir que un Juez designado después del hecho conozca y revuelva el caso, pues esto no sólo que no cumpliría la función teleológica del mismo, sino que sería de imposible aplicación; pues, ni aún existiendo jueces vitalicios podría cumplirse tal exigencia, que como ha quedado establecido no está presente en el espíritu de la norma ${ }^{101}$. En definitiva, el Tribunal Constitucional de Bolivia entendió que el espíritu del juez natural, alcanza a aquel que formalmente ha sido designado con posterioridad al hecho de la causa que se juzga ${ }^{102}$, ya que materialmente su competencia se encuentra fijada con criterios objetivos establecidos con carácter previo por la ley, cuestión sobre la que la CIDH todavía no se ha pronunciado

$\mathrm{La}$ CIDH, en muchísimos casos como los antes mencionados ${ }^{103}$, ha tenido que otorgar protección a las personas particulares, frente a los atropellos que en los procesos administrativos militares, han sido cometidos por ese tipo de jurisdicción, dejando sentado varios razonamientos, entre ellos que la jurisdicción militar no puede dictar sentencias contra particulares por ilícitos de tipo común, que la jurisdicción militar solo está para juzgar a militares por delitos de esa misma naturaleza y no otra, o lo que es lo mismo, cuando un tribunal militar juzga asuntos que debe conocer la justicia ordinaria, se convierte en un tribunal especial, creado para el caso o ad hoc.

La jurisprudencia desarrollada por la $\mathrm{CIDH}$, con relación a la violación al derecho a un juez natural por usurpar jurisdicción, actuar sin competencia o trasladarla de la ordinaria a la militar, en temas de juzgamiento de civiles por jueces militares, o de militares por delitos comunes o tribunales sin rostro conocido, etc., ha sido asumida no solo por el TEDH como se ha señalado, sino que de manera significativa también ha sido acogida por tribunales nacionales de la región andina.

Entre los países andinos estudiados, Perú y Bolivia han atravesado dictaduras con gobiernos y tribunales militares que han vulnerado derechos humanos, lesiones que han sido protegidas por sus tribunales constitucionales, que

${ }^{101}$ Considerando 5, punto 3.

102 Pese a que en su literalidad la norma se refiere al juez designado con anterioridad al hecho de la causa.

${ }^{103}$ Sentencia de 18 de agosto de 2000 en el Caso Cantoral Benavides Vs. Perú; Sentencia de 06 de diciembre de 2001 en el Caso Las Palmeras Vs. Colombia; Sentencia de 05 de julio de 2004, en el Caso 19 Comerciantes Vs. Colombia; Sentencia de 25 de noviembre de 2004, en el Caso Lori Berenson Mejía Vs. Perú; entre muchas otras. 
de manera expresa e implícitamente han acogido la jurisprudencia internacional cuando han considerado que la competencia de los tribunales militares está dada para el juzgamiento de militares y no de civiles, sin embargo esas autoridades militares pueden ser juzgados por la justicia ordinaria cuando comenten delitos de tipo común; evidenciando una misma línea e igual razonamiento entre la CIDH y los tribunales estatales de Bolivia y Perú, como se pasa a constatar.

En temas de competencia militar, el Tribunal Constitucional del Perú, en una acción de hábeas corpus, en el Expediente n. ${ }^{\circ}$ 0217-2002-HC/TC, dentro del que se dictó la Sentencia de 17 de abril de 2002, hizo mención expresa al razonamiento que tuvo la CIDH en el Caso del Tribunal Constitucional Vs. Perú ${ }^{104}$, que le permitió llegar a la convicción de que: «encontrándose el ámbito de la competencia de la justicia militar reservado sólo para el juzgamiento de militares en caso de delitos de función y, excepcionalmente, para los civiles, siempre que se tratase del delito de traición a la patria, cometido en caso de guerra exterior, no podía juzgársele al recurrente en dicho fuero militar» ${ }^{105}$; constatándose que un traslado de competencia que violaría el derecho al juez natural competente.

Como consecuencia de una acción de inconstitucionalidad, el mismo Tribunal Constitucional del Perú, en el Expediente n. ${ }^{\circ} 010-2002-A I / T C$ emitió la Sentencia de 03 de enero de 2003, por la que declaró inconstitucionales, una serie de normas legales, que preveían que tribunales militares -en delitos de traición a la patria o de terrorismo-, puedan ser competentes para juzgar a civiles ${ }^{106}$; entre los argumentos utilizados fueron: «no considerar que sean los tribunales militares los facultados para conocer los procesos seguidos contra civiles ... pues ello implicaría una afectación del derecho constitucional al juez natural» ${ }^{107}$; asimismo se expresó que: «las disposiciones del Código de Justicia Militar no tienen por finalidad regular ... los delitos e infracciones cometidos por civiles, sino las cometidas por militares en situación de actividad ${ }^{108}$.

En la referida Sentencia, cabe resaltar que las interpretaciones efectuadas, partieron de manera expresa de los criterios que la CIDH desarrollo, en el Caso Castillo Petruzzi ${ }^{109}$, también en el Caso Cantoral Benavides ${ }^{110}$, así como

\footnotetext{
105 Ibidem. Decreto Ley n. ${ }^{\circ} 25708$.

107 Punto 10.2.a.105.

108 Punto 10.2.a.107.

109 Punto 10.2.98.

${ }^{110}$ Punto 10.2.99.
}

${ }^{104}$ Punto 2 de Fundamentos.

${ }^{106}$ Se declaró la inconstitucionalidad del artículo $4 .^{\circ}$ del Decreto Ley n. ${ }^{\circ} 25659$ y el artículo $2 .^{\circ}$ del Decreto Ley n. ${ }^{\circ} 25880$ y, por conexión, también los artículos $2 .^{\circ}$ y $3 .^{\circ}$ del 
en el Caso Castillo Petruzzi ${ }^{111}$, señalando que: «Tribunal Constitucional comparte tales preocupaciones» con relación a: «La autorización para que los tribunales militares juzguen a civiles por los delitos de traición a la patria y terrorismo» ${ }^{112}$.

El Tribunal Constitucional de Bolivia emitió la SC n. ${ }^{\circ}$ 0663/2004-R de 5 de mayo, como consecuencia de juzgamiento y procesamiento a militares por la jurisdicción ordinaria y no militar ${ }^{113}$ señaló que el que: «la justicia militar hubiera tenido prevención en el conocimiento de la causa, que esta previsión de orden procesal no es aplicable al caso en virtud de que no se trata de órganos que tengan competencia en el mismo ámbito jurisdiccional, pues el uno lo hace en la jurisdicción ordinaria y el otro en la jurisdicción militar» ${ }^{144}$.

Al realizar su análisis, el Tribunal Constitucional de Bolivia también expresó que: «El tema ha sido motivo de pronunciamiento de la CIDH. Citamos lo pertinente de la sentencia de 16 de septiembre de 2000 emitida por dicho órgano internacional» ${ }^{115}$; en esta cita, nuevamente este Tribunal vuelve a incurrir en imprecisiones, porque no señala el caso en el que se pronunció la sentencia. Con ese contenido no existe ninguna de 16 de septiembre de 2000 , sino que se estaban refiriendo al contenido y lo señalado por la Sentencia de 16 de agosto de 2000, en el Caso Durand y Ugarte Vs. Perú.

También el Tribunal Constitucional de Bolivia, conoció otro caso en temas de militares, que se encuentra contenido en la SC 0664/2004-R de 06 de mayo, en el que no se refirió de manera expresa a ninguna Sentencia de la $\mathrm{CIDH}$, sin embargo resulta evidente que asumió de manera íntegra los razonamientos que ya dio ese tribunal internacional, pues partiendo del hecho de que los: «los militares fueron imputados por la comisión de delitos comunes» ${ }^{116}$, «se concluye, que los supuestos delitos cometidos por los militares imputados, tienen que ser conocidos por los jueces y tribunales ordinarios» ${ }^{117}$, finalmente sobre esa base se afirmó que: «la jurisdicción militar está reservada al ámbito estrictamente militar, es decir a los delitos de

111 Punto 10.2.100.

112 Punto 10.2.a.102.

113 Lo que motivó la decisión constitucional, tiene como antecedentes los hechos luctuosos que se produjeron en el mes de febrero de 2003, disponiendo que los cuatro militares acusados de haber matado y herido, sean procesados y juzgados en la jurisdicción ordinaria y no así en la militar.

114 Punto III.6 de Fundamentos.

115 Ibidem; razonamientos que se refieren a que debe estar excluido del ámbito de la jurisdicción militar el juzgamiento de civiles y sólo debe juzgar a militares por la comisión de delitos o faltas que por su propia naturaleza atenten contra los bienes jurídicos propios del orden militar.

116 Punto III.2.2 de Fundamentos.

117 Punto III.2.3. de Fundamentos. 
función, entre los que no se encuentran ... los delitos presuntamente cometidos por los militares imputados $\gg{ }^{118}$.

En consecuencia, las determinaciones asumidas por el Tribunal Constitucional de Bolivia, en las señaladas SS.CC. Nos. 0663/2004-R y 0664/2004$\mathrm{R}^{119}$, ha sido emitidas en resguardo del derecho a un juez natural competente, que tratándose de delitos comunes cometidos por los militares, no es otro que la jurisdicción ordinaria; como entendió la CIDH.

Obligada aquí es la referencia a los llamados jueces «sin rostro», valorados por la CIDH el marco de la competencia y como una violación a ella; pese a que stricto sensu, esos casos se acercan más a una violación del juez imparcial, que de juez competente, pues agravia la imparcialidad del juzgador cuando quienes están siendo juzgados desconocen la identidad de la persona que va a resolver y decidir su caso; con esta aclaración, con relación a la ubicación que hace la CIDH, se pasa a realizar alguna mención en el presente acápite.

En la mencionada Sentencia del Caso Loayza Tamayo Vs. Perú, además de la doctrina relativa a la usurpación de jurisdicción y como consecuencia, actuación sin competencia, a tiempo de valorar la competencia también ha puesto en debate el tema relativo a los «tribunales sin rostro», que como parte de la normatividad antiterrorista peruana, se encontraban reconocidos en su legislación; así se señaló como un hecho probado por la Corte que la Sra. Loayza Tamayo, fue: «juzgada ... en el fuero militar ... por «jueces sin rostro» ${ }^{120}$, lo que también dio lugar a la protección demandada.

El alcance de los tribunales sin rostro, se aclaró en el Caso Castillo Petruzzi y otros c. Perú, en 1999, cuando se expresó que: «la circunstancia de que los jueces intervinientes en procesos por delitos de traición a la patria sean «sin rostro», determina la imposibilidad para el procesado de conocer la identidad del juzgador y, por ende, valorar su competencia» ${ }^{121}$, situación injusta que ha motivado la protección internacional demandada, en cuanto constituye una vulneración al art. 8.1 de la $\mathrm{CADH}$, el que un tribunal militar «sin rostro» o cuya identidad se ignora por completo, juzgue a una persona particular inculpada de la supuesta comisión de un ilícito que es de naturaleza común y no militar.

118 Ibidem.

119 Esas decisiones, provocaron una dura reacción de los militares, que inclusive llegaron a generar crisis y desestabilizaron al gobierno de la época, que se encontraba a la cabeza del entonces Presidente Carlos D. Meza.

120 Párrafo 46 inc. i); como consecuencia del pronunciamiento de la Corte Interamericana, el Estado de Perú, posteriormente emitió la Ley 26671 de 15 de octubre de 1997, en la que en su artículo único estableció que los magistrados encargados de juzgamiento de los acusados por terrorismo, deberían estar debidamente designados e identificados.

121 Párrafo 133. 
Con relación a los tribunales sin rostro conocido, en el señalado expediente n. $^{\circ}$ 010-2002-AI/TC, ante la demanda de declaración de inconstitucionalidad de la norma que disponía que la identidad de los magistrados y los miembros del Ministerio Público, así como la de los auxiliares de justicia que intervinieran en el juzgamiento de los delitos de terrorismo será secreta ${ }^{122}$, el Tribunal Constitucional considero que carecía de objeto pronunciarse sobre la misma, en cuanto la disposiciones cuestionada fue superada con la disposición del artículo único de la Ley n. ${ }^{\circ} 26671$ de 15 de octubre de 1997, que previó que: «los magistrados encargados del juzgamiento de los acusados por los delitos de terrorismo ... serán debidamente designados e identificados ${ }^{123}$.

Como consecuencia del planteamiento de una acción de habeas corpus, dentro del que el Tribunal Constitucional del Perú dictó la Sentencia de 04 de diciembre de 2003, en el Expediente n. ${ }^{\circ}$ 0516-2003-HC/TC, con relación a los jueces sin rostro, se manifestó que el: «hecho de desconocer la identidad de los magistrados encargados de llevar a cabo el juicio oral en contra del beneficiario lesionó el derecho al juez natural, toda vez que el justiciable no estaba en la capacidad de poder conocer con certeza quiénes eran aquellas personas que lo juzgaban y condenaban ${ }^{124}$, razonamiento que se dio asumiendo de manera expresa la interpretación que al respecto realizó la CIDH en el Caso Castillo Petruzzi y otros Vs. Perú.

\subsection{Juez independiente}

El contexto constitucional de países de la región andina, contiene normas que garantizan la independencia de las autoridades encargadas de la administración de justicia; así la Constitución Política del Perú de 1993, que en su art. 141.1 el art. 230 de la Constitución de la República de Colombia de 1991 (con reformas hasta el 2005), artículo 120.I. de la Constitución Política del Estado Plurinacional de Bolivia de 2009.

La independencia del juzgador implica: «autonomía, frente a cualquier otro órgano del Estado, para ejercer funciones jurisdiccionales, como consecuencia de la aplicación de la doctrina de la separación de poderes, base del sistema democrático» ${ }^{125}$; principio de separación de poderes e independencia que aseguran que cada órgano del Estado actúe en forma libre, sin injerencia

${ }^{122}$ Artículo $15 .^{\circ}$ Decreto Ley n. ${ }^{\circ} 25475$.

${ }^{123}$ Punto 10.2.b.111. La Ley n. ${ }^{\circ} 26671$ de 15 de octubre de 1997 se emitió como consecuencia de los fallos de la Corte Interamericana, que cuestionaron el contenido del art. 15 del Decreto Ley n. ${ }^{\circ} 25475$ por ser violatorio al juez natural competente.

${ }_{124}$ Punto 2 de Fundamentos.

125 Cecilia Medina Quiroga, La Convención ..., 298. 
y menos imposiciones o amedrentamientos, que provengan de otros órganos, lo que se logra solo cuando en un Estado existe un sistema político maduro.

Sin embargo, es necesario tener en cuenta que dichos principios de separación de funciones e independencia, son incompatibles con los principios de principios de jerarquía y obediencia, que hay que analizarlos dentro de los alcances de una jurisdicción militar.

Fue el caso en mayo de 1999 Castillo Petruzzi y otros Vs. Perú, en el que se empezó a considerar esta incompatibilidad, cuando se manifestó que «el tribunal de segunda instancia forma parte de la estructura militar. Por ello no tiene la independencia necesaria para actuar ... pese a la existencia ... de recursos ... aquéllos no constituyen una verdadera garantía de reconsideración del caso» ${ }^{126}$; en la misma línea se trabajó el año 2004, en el Caso Lori Berenson Mejía Vs. Perú ${ }^{127}$.

Los razonamientos relativos al encuentro que se produce entre el principio de separación de órganos e independencia, con los de jerarquía y obediencia dentro del ámbito militar, han sido acogidos por el Tribunal Constitucional del Perú, en el Expediente n. ${ }^{\circ}$ 0023-2003-AI/TC, en el que manifestó que «los principios de independencia ... además del principio de separación de poderes ... es incompatible que personas sujetas a los principios de jerarquía y obediencia, como los profesionales de las armas que ejercen funciones jurisdiccionales, puedan ser al mismo tiempo» ${ }^{128}$, esta interpretación se ha efectuado sin remitirse a algún caso de la CIDH, pero si asumiendo de manera absoluta los criterios que al respecto manifestó esa instancia internacional.

Esa incompatibilidad, ha sido más ampliamente desarrollada por ese mismo Tribunal en el Expediente n. ${ }^{\circ}$ 0004-2006-PI/TC, cuando expresó que a:«diferencia de los órganos de la «administración militar», los órganos de la «jurisdicción militar» no pueden orientarse, entre otros, por los principios de obediencia y subordinación», pues «entre un juez penal militar de primera instancia y un juez penal militar de segunda instancia no existe subordinación y dependencia, pues ambos se encuentran protegidos mediante la garantía institucional de la independencia judicial» ${ }^{129}$; en este punto tampoco citó precedente de la CIDH, pero asumió su criterio.

Es necesario hacer mención exclusiva a la relación de los principios de independencia judicial y separación de órganos o de distribución de funciones, sobre los cuales el Tribunal Constitucional del Perú desarrolló una doctrina complementaria a la expresada por la CIDH; así en el referido Expediente

\footnotetext{
126 Párrafo 161.

127 Párrafo 193.

128 Punto 6.42.

${ }^{129}$ Punto 2.2.67.
} 
n. ${ }^{\circ}$ 0023-2003-AI/TC, analizó al principio de independencia judicial desde tres perspectivas: «a) Como garantía del órgano que administra justicia (independencia orgánica), por sujeción al respeto al principio de separación de poderes. b) Como garantía operativa para la actuación del juez (independencia funcional), por conexión con los principios de reserva y exclusividad de la jurisdicción. c) Como capacidad subjetiva, con sujeción a la propia voluntad de ejercer y defender dicha independencia $\rangle^{130}$.

El razonamiento señalado no se ha quedado a nivel de una independencia orgánica de los diferentes órganos del Estado que administran justicia, relacionado con el principio de separación de atribuciones o funciones; sino que va más allá a una independencia funcional relacionada con otros principios como son los de reserva y exclusividad de la jurisdicción; así como al ámbito personal del juzgador, sustentada en la convicción y fuerza que debe tener para hacer cumplir la independencia; estas interpretaciones son un avance y complemento a las efectuadas por la CIDH.

En el ejercicio de sus funciones estatales, las manifestaciones de voluntad que realizan los cargos representativos no son personales, sino que son imputables al órgano del Estado del cual forman parte, por lo que pueden conllevar responsabilidad internacional del Estado al que representa.

Ese tipo de responsabilidad internacional se dio en relación con el Estado del Perú, en el Caso Tribunal Constitucional ${ }^{131}$, que respondía a un juicio político que se llevó a instancias del Órgano Legislativo ${ }^{132}$, contra tres autoridades del Órgano Judicial, que fueron destituidos de sus funciones de magistrados del Tribunal Constitucional, por haber emitido un fallo contra los intereses del Presidente del Estado, cabeza del Órgano Ejecutivo, que tenía fuerza e influencia política sobre el Órgano Legislativo.

\section{Punto 5.31.}

131 Esta Sentencia de 31 de enero de 2001, en el Caso del Tribunal Constitucional Vs. Perú, tiene como hechos fácticos la Ley n. ${ }^{\circ} 26.657$ o Ley de Interpretación Auténtica del artículo 112 de la Constitución, promulgada el 23 de agosto de 1996, que establecía que la reelección presidencial «está referida y condicionada a los mandatos presidenciales iniciados con posterioridad a la fecha de promulgación del referido texto constitucional ... en el cómputo no se tienen en cuenta retroactivamente, los períodos presidenciales iniciados antes de la vigencia de la Constitución». Esta Ley por una parte dio lugar a que el Presidente Alberto Fujimori inscribiera su candidatura y; por otra parte a que el Colegio de Abogados de Lima presentara una acción de inconstitucionalidad contra la Ley No. 26.657, por la violación del artículo 112 de la Constitución; el tribunal Constitucional declaró «INAPLICABLE, la ley interpretativa n. ${ }^{\circ} 26.657$ y como consecuencia los tres magistrados que emitieron su voto en el caso, fueron destituidos de sus cargos por el Poder Legislativo, en el marco de un juicio político que se les siguió; luego de sus reclamos nacionales, presentaron su acción a nivel internacional.

${ }^{132}$ Siempre recordando que cualquier órgano del poder público puede tener función jurisdiccional. 
Esa injusta situación, motivó que la CIDH, en el referido caso reconociera que «la destitución de las tres supuestas víctimas fue producto de la aplicación de una sanción por parte del Poder Legislativo en el marco de un juicio político» ${ }^{133}$ y que el «ejercicio de las atribuciones del Congreso para llevar a cabo un juicio político» ${ }^{134}$ está relacionado con el derecho de toda persona que se encuentra «sujeta a juicio de cualquier naturaleza ante un órgano del Estado deberá contar con la garantía de que dicho órgano sea competente, independiente e imparcial» ${ }^{135}$.

La tramitación de juicios políticos no garantiza ni asegura un proceso con juez natural independiente, pues «un órgano de naturaleza política, como es el Legislativo, no reúne las mínimas condiciones de imparcialidad en la tramitación de un proceso ... de naturaleza sancionadora» ${ }^{136}$, siendo varias las razones, como es que «su composición está caracterizada por la presencia de políticos, más que juristas con experiencia en la función judicial ${ }^{137}$. Por otro lado, ciertas instituciones de representación política ${ }^{138}$, tendrán el control de la mayoría en las Cámaras del Órgano Legislativo, en esa medida ante una acusación planteada por el Órgano Ejecutivo ${ }^{139}$ «esa mayoría parlamentaria actuará con consigna y sobre la base de la disciplina partidaria» ${ }^{140}$; lo que indudablemente no garantiza el derecho al juez natural independiente.

Por el principio de independencia se repudia todo tipo de coacción, que está muy presente en juicios de tipo político, por eso de manera correcta se manifestó que: «nada más oprobioso que la existencia de jueces políticos, de funcionarios al servicios de los gobernantes o de los partidos políticos $\rangle^{141}$, el mismo autor manifestó su preocupación porque son: «gravísimas las consecuencias de permitir que ... la justicia esté a merced de la política y los políticos $\rangle^{142}$.

En los Estados en los que no existe madurez política, se tramitan juicios de tipo político, donde las actuaciones de las autoridades jurisdiccionales,

133 Párrafo 67.

134 Párrafo 77.

135 Ibidem.

136 José Antonio Rivera SantivañEz, Análisis de la Nueva Constitución Politica del Estado, Instituto de Investigaciones Jurídicas de la UNAM, 34. Este material puede darse lectura en: www.juridicas.unam.mx.

${ }^{137}$ Ibídem.

${ }^{138}$ Como son el Bolivia los partidos políticos, las agrupaciones ciudadanas y los pueblos indígenas.

139 Órgano Ejecutivo que no en pocas ocasiones busca impedir un control de constitucionalidad o de legalidad por el Órgano Judicial.

140 Rivera Santivañez, Análisis ..., 134.

141 Devis Echandía, Teoría ..., 56.

142 Ibidem, p. 130. 
lejos de caracterizarse por la independencia, se encuentran sometidos a mandatos e intromisiones de otros órganos del poder público, con una clara violación a una de las garantías mínimas del debido proceso, que es el derecho a un juez natural independiente.

La independencia del juzgador se materializa a través de una serie de mecanismos mencionados la CIDH, en el señalado Caso Tribunal Constitucional Vs. Perú, cuando manifestó que: «la garantía de la independencia de los jueces y, para tales efectos, los diferentes sistemas políticos han ideado procedimientos estrictos, tanto para su nombramiento como para su destitución» ${ }^{143}$; posteriormente indica «como lo señalara la Corte Europea, la independencia de cualquier juez supone que se cuente con un adecuado proceso de nombramiento, con una duración establecida en el cargo y con una garantía contra presiones externas ${ }^{144}$; además de estos mecanismos, el TEDH en las sentencias asumidas por la CIDH, reconoce otro que es el relativo a que: «el órgano presenta una apariencia de independencia».

De acuerdo a esa doctrina, los procedimientos con los cuales se logra independencia jurisdiccional están relacionados con: la forma de nombramiento, la duración en el cargo y la forma de destitución, que aseguran la existencia de un juez independiente, frente a presiones externas que se puede ejercer contra la autoridad jurisdiccional, además de la necesaria apariencia de independencia del órgano; esa doctrina tiene como fuente el razonamiento del TEDH (como reconoció la propia CIDH).

La forma de designación de autoridades judiciales, no tuvo una misma solución en todos los tiempos y en todos los países. La mayoría de los países de América, ha adoptado la posición que la designación de las autoridades del órgano judicial y/o de tipo jurisdiccional se realiza por el Órgano Legislativo (sea denominado Congreso, Asamblea, Parlamento u otro nombre); en el caso de los países de la Región Andina en estudio, por ejemplo se observa que en el Perú los magistrados del Tribunal Constitucional son elegidos por el Congreso de la República, con el voto favorable de los dos tercios del número legal de sus miembros ${ }^{145}$; a su vez en Colombia los Magistrados de la Corte Constitucional serán elegidos por el Senado de la República $^{146}$.

143 Párrafo 73.

144 Párrafo 75. La referencia que realiza la Corte Interamericana a la fuente, no es otra que un razonamiento de la Corte Europea o Tribunal Europeo de Derechos Humanos, señalándose como precedentes el Caso Campbell y Fell Vs. Reino Unido, Sentencia de 28 de junio de 1984, párr. 76 y 78 y; Caso Langborger Vs. Suecia, Sentencia de 22 de junio de 1989 , párr. 32.

145 Art. 204 párrafo III de la Constitución Política de Perú.

146 Art. 239, párrafo II de la Constitución Política de la República de Colombia. 
Ese tipo de nombramiento realizado por el Órgano Legislativo, ha creado en el ciudadano cierta desconfianza porque los magistrados serían: «designados por el Congreso sobre la base de un cuoteo que en el desempeño de sus labores se subordinan a la voluntad política de los partidos que los designan» ${ }^{147}$; así también se manifestó: «Los nombramientos discrecionales para ... Magistrados del Tribunal Supremo y Constitucional han estado, por lo general, manchados de la impronta partidocrática que el órgano tiene» ${ }^{148}$.

En busca de un cambio que supere las debilidades de la administración de justicia, partiendo de su forma de nombramiento, en Bolivia se cambia el sistema de una designación por autoridades del Órgano Legislativo, a una elección popular ${ }^{149}$, en el marco de las reformas constitucionales que se han introducido en la CPE de 2009, cuyos arts. 182-I, 188-I, 194-I y 198, señalan que las y los Magistrados del Tribunal Supremo de Justicia, Tribunal Agroambiental, Consejo de la Magistratura y Tribunal Constitucional Plurinacional, serán elegidos mediante sufragio universal.

La elección popular de autoridades del Órgano Judicial, provoca un riesgo de politización, que puede restar de manera considerable la independencia que deben tener los órganos jurisdiccionales, es que la representación popular está circunscrita al campo de lo político: «por eso se vota por los representantes en los poderes legislativo y ejecutivo. En cambio, la función de los magistrados de los más altos tribunales de un país se caracteriza justamente por ser no política ... no se "deben" a ningún electorado, sólo se "deben" a su conciencia» ${ }^{150}$; asimismo se manifestó que el imponer la elección directa por voto popular: «contribuye a que la politización se haga efectiva y se elimine la independencia de los jueces y magistrados $\rangle^{151}$, autoridades que a partir de su elección tendrán que tener habilidad política más que honestidad y capacidad técnica, pues: «los ciudadanos que voten por un determinado postulante exigirán un comportamiento de la autoridad acorde

147 Rivera SantivañEZ, Análisis de la ..., 142.

148 Rafael JIMÉNEZ AsENSIO, «Imparcialidad judicial y derecho al juez imparcial en la Constitución de 1978» en La imparcialidad judicial, ed. Por Consejo General del Poder Judicial, (Madrid, 2008), 19.

149 El voto popular, como un medio para elegir autoridades judiciales, solo tiene como antecedente el caso de Estados Unidos, en el que 30 Estados Federados eligen por voto popular a jueces de inferior jerarquía; manteniéndose la designación por el Legislativo de otras autoridades judiciales, a propuesta de su Presidente.

150 Juan Carlos Urenda, «El Problema de Fondo de la Elección de Magistrados». Instituto Libertad, Democracia y Empresa, www.institutoilde.org. Publicado el 17 de octubre de 2011.

151 José Antonio Rivera Santivañez, Estudios Sobre la Constitución Aprobada de enero de 2009 (Cochabamba: Ed. Kipus, 2009), 40. 
con su voluntad política, exigirán rendición de cuentas y aplicarán revocatoria de mandato» ${ }^{152}$.

Entre los mecanismos que aseguran la independencia, está el relativo a que el órgano que va a juzgar, presente una apariencia de independencia, pues caso contrario se viola el derecho al juez natural independiente; este criterio ha sido reconocido expresamente por el TEDH, pero asumido por la CIDH de manera implícita en una serie de casos que se han dado vinculados al juzgamiento que realizan las autoridades militares.

Ya el TEDH en 1988 entendió que los miembros de un tribunal que tienen una relación significativa con alguna de las partes, plantean dudas sobre su independencia e imparcialidad, como se da tratándose de tribunales penales militares, que generan desconfianza en la víctima por la forma de designación de los miembros del tribunal marcial, que muchas veces son inferiores de rango con relación al que juzgan y caen dentro de una cadena de mando. Sin así decirlo, la CIDH asume la misma posición que el TEDH en diversos casos, razonamiento que también ha sido reiterado por el Tribunal Constitucional del Perú, que si tiene referencias específicas a la jurisprudencia de la CIDH.

los razonamientos en cuanto al tema de nombramiento y su relación con la independencia de la autoridad jurisdiccional, han sido asumidos por el Tribunal Constitucional del Perú, en el Expediente n. ${ }^{\circ}$ 0023-2003-AI/TC, que corresponde a la Sentencia emitida el 09 de junio de 2004, en la que se ha citado de manera expresa a la Sentencia del Caso Castillo Petruzzi emitida por la CIDH, señalando que: «no está garantizada la independencia del juez militar frente al Poder Ejecutivo desde el momento en que éste nombra a ... Jueces ... La intervención del Poder Ejecutivo, directa o indirectamente, en el nombramiento de los jueces militares, representa un atentado contra la independencia judicial y la garantía de imparcialidad $»^{153}$.

Asimismo, dicho Tribunal Constitucional del Perú, en Sentencia de inconstitucionalidad de 29 de marzo de $2006^{154}$, pronunciada dentro del Expediente 0004-2006-PI/TC, se remitió de manera expresa al Caso Palamara Iribarne Vs. Chile pronunciado por la $\mathrm{CIDH}$, declarándose inconstitucionales, una serie de disposiciones relativas al nombramiento de autoridades militares por el órgano Ejecutivo, por vulnerar el principio de independencia.

Otro de los mecanismos que aseguran la existencia de un juez independiente, es el referido a la duración del mandato, vinculado al mecanismo

152 Rivera Santivañez, Análisis de la ..., 144.

153 Punto 6.58.

${ }^{154}$ Que se pronunció como consecuencia de una acción de inconstitucionalidad planteada por la Fiscal de la Nación contra una serie de disposiciones relativas a la Organización, Funciones y Competencia de la Jurisdicción Especializada en Materia Penal Militar Policial. 
referido a la existencia de garantías contra presiones externas ${ }^{155}$, que solo se asegura con la inamovilidad del juzgador, que no se da cuando se produce su arbitraria destitución; o dicho de otra manera, se protege la remoción durante el mandato de un juzgador, a través de la inamovilidad, salvo causas legalmente establecidas.

Tanto los jueces de carrera, como los magistrados de altas cortes, gozan de estabilidad en el desempeño de sus cargos, los unos durante el tiempo de su carrera judicial, los otros dentro del período de funciones para el que han sido designados o elegidos; estabilidad que se materializa con el principio de inamovilidad de los jueces que: «se establece como un valladar contra la remoción y el apartamiento de una causa, impuesta por la vía del traslado sin consentimiento, convirtiéndose, por ende, en un resguardo seguro para la permanencia en la sede y en el grado» ${ }^{156}$.

La CIDH ha entendido como un principio que: «crea estabilidad en la magistratura; si el juez ha de ser removido, dicha remoción debe llevarse a cabo en estricta conformidad con los procedimientos establecidos en la Constitución», señalando también que: «el principio -de inamovilidad- se basa en la propia naturaleza especial de la función de los tribunales y garantiza la independencia de los jueces frente a las demás ramas del gobierno y ante los cambios político-electorales ${ }^{157}$.

En cuanto a la destitución de los jueces, la CIDH en el señalado Caso del Tribunal Constitucional Vs. Perú, manifestó que: «la autoridad a cargo del proceso de destitución de un juez debe ... permitir el ejercicio del derecho de defensa» ${ }^{158}$; es decir que por los principios de independencia de los jueces y tribunales, así como por el de inamovilidad ${ }^{159}$, en caso de producirse un proceso en contra de esa autoridad jurisdiccional (que puede terminar o no con sanción de destitución), es necesario que se respete las garantías mínimas al debido proceso, como es su derecho a la defensa y también su derecho de ser juzgados por autoridades independientes.

El Tribunal Constitucional del Perú, en el Expediente EXP. n. ${ }^{\circ} 0023-$ 2003-AI/TC, señaló que: «la garantía de la inamovilidad de los jueces durante su mandato ... debe entenderse, a su vez, como una garantía de

155 Ambos mecanismos señalados por el TEDH, en el indicado caso Campbell y Fell Vs. Reino Unido.

${ }^{156}$ Francisco Fernández Segado, El Sistema Constitucional Español, (Madrid-Españ: Ed. Dykinson, 1992), 1065.

${ }^{157}$ CIDH Informe n. ${ }^{\circ}$ 30/97 de 30 de septiembre, en el Caso 10.087, Gustavo Carranza Vs. Argentina, párrafo 41.

158 Párrafo 74.

159 Inamovilidad que alcanza a los mecanismos de permanencia en el cargo y terminación de su ejercicio. 
justicia para el administrado, indispensable para reforzar la independencia judicial en un Estado Democrático» ${ }^{160}$, al referirse a la posición que sumió la $\mathrm{CIDH}$.

Es decir que los jueces $\mathrm{y} /$ magistrados, al igual que cualquier funcionario público, gozan de inamovilidad y estabilidad en el desarrollo de sus funciones -por el tiempo que en cada caso pueda corresponder-, pudiendo ser destituidos o separados de sus actividades, solo cuando se ha observado a su favor un debido proceso en tiempo oportuno y razonable, que se tramite con las garantías mínimas de defensa e imparcialidad, además de contar con una decisión jurisdiccional debidamente motivada y fundamentada.

Finalmente es necesario referirse al Expediente EXP. n. ${ }^{\circ} 0023-2003-\mathrm{AI} /$ TC, en cuya sentencia el Tribunal Constitucional del Perú, entendió que la inamovilidad, debe tenerse en cuenta dos aspectos: «a) Prohibición de separación de la carrera judicial, salvo proceso sancionatorio y/o sometimiento a la ratificación judicial (al que ya se hizo mención). b) Prohibición de traslados forzosos de un puesto judicial a otro» ${ }^{161}$.

El traslado debe prohibirse porque pone en peligro la estabilidad del juez en su cargo y su carrera judicial, ya que «no podría verificarse con las separaciones o traslados no justificados ni establecidos en norma alguna, y mucho más cuando provengan de un órgano distinto, como el Poder Ejecutivo» ${ }^{162} ; \mathrm{y}$ en el ámbito de la jurisdicción militar, se viola el juez independiente, pues: «por la propia naturaleza de las funciones de los miembros del servicio activo ..., resultan susceptibles de rotación, y no necesariamente para seguir desempeñando las mismas funciones jurisdiccionales» ${ }^{163}$.

El haberse incluido el traslado, como un mecanismo más que asegura la independencia de los jueces, refleja el carácter garantista y desarrollado que tiene el Tribunal Constitucional del Perú, complementando la línea del TEDH, asumida por la CIDH, al reconocerse al traslado como un medio más de garantía al derecho de las personas a un juez independiente.

\subsection{Juez imparcial}

La doctrina de la doble dimensión de la imparcialidad que partió del TEDH, tampoco ha estado ajena del desarrollo de la jurisprudencia de la $\mathrm{CIDH}$, que el 2008, asume de manera expresa y específica aquella, cuando

\footnotetext{
160 Punto 5.35.2.

161 Punto 5.35.2.

162 Ibídem.

163 Punto 5.36.
} 
considera que la imparcialidad se compone de dos elementos: subjetivo y objetivo, en exacto sentido de lo señalado por el TEDH ${ }^{164}$.

Pese a la existencia de diversas clasificaciones ${ }^{165}$, se hará mención a la imparcialidad subjetiva y objetiva, en la medida que esa clasificación, ha sido y es la más asumida en el medio judicial.

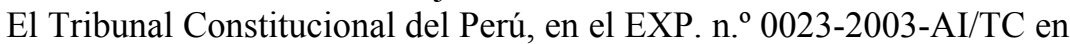
Sentencia de 09 de junio de 2004, hizo mención a las dos acepciones objetiva y subjetiva de la imparcialidad, señalando como fuente de su razonamiento casos del TEDH ${ }^{166}$, expresando que: «el principio de imparcialidad ... se vincula a determinadas exigencias dentro del proceso, definidas como la independencia del juez frente a las partes y al objeto del proceso» ${ }^{167}$, asimismo detalló las dos acepciones del principio de imparcialidad, tal la: «a) Imparcialidad subjetiva, que atañe a algún tipo de compromiso que el juez pueda tener con el caso. b) Imparcialidad objetiva ... el sistema no ofrece suficientes garantías para desterrar cualquier duda razonable» ${ }^{168}$.

En este caso se toma como fuente únicamente la jurisprudencia del TEDH y no así de la CIDH, no solo porque en el tema de las acepciones de la imparcialidad, asimiló la jurisprudencia desarrollada por el Sistema Europeo de Protección, sino porque el fallo interamericano fue pronunciado con posterioridad al estatal.

Cuando cualquiera de las partes considera que la autoridad judicial es parcial pueden estas acudir a la recusación. Ésta se constituye en un medio para separar al juez de la causa, por existir elementos que provocan dudas razonables y fundadas, en sentido de que el proceso no será resuelta con imparcialidad, sino con interés personal del juzgador o en sentido de que se favorecerá a uno de los sujetos procesales;

Esta institución se convierte: «no sólo en un derecho de la parte, sino también en una garantía del proceso justo, que se puede activar cuando fallan los mecanismos tradicionales de la inhibición o abstención por parte de los miembros de la propia judicatura ${ }^{169}$;

${ }^{164}$ Caso Apitz Barbera y otros Vs. Venezuela, Sentencia de 05 de agosto de 2008, párr. 56, que asume el razonamiento de casos resueltos por el TEDH; tales: Pullar Vs. Reino Unido, sentencia de 10 de junio de 1996; Fey Vs. Austria, Sentencia de 24 de febrero de 1993; Daktaras Vs. Lituania; Piersack Vs. Bélgica, Sentencia de 1 de octubre de 1982; De Cubber Vs. Bélgica, Sentencia de 26 de octubre de 1984.

165 Vide Salvador Guerrero Palomares, La imparcialidad objetiva del juez penal. Análisis jurisprudencial y valoración crítica, (Navarra: Ed. Aranzadi, 2009), 167.

166 Se hizo mención al Caso De Cubber contra Bélgica, del 26 de octubre de 1984, entre otros.

167 Punto 5.34.

168 Ibidem.

169 JiMÉneZ AsEnsio, Imparcialidad ..., 250. 
En el Caso Apitz Barbera y otros Vs. Venezuela, la CIDH, entendió que la recusación tiene una doble finalidad: «por un lado actúa como una garantía para las partes en el proceso, y por el otro, busca otorgar credibilidad a la función que desarrolla la Jurisdicción $»{ }^{170}$, en función a esa finalidad define a la recusación como: «una herramienta que brinda confianza a quienes acuden al Estado solicitando la intervención de órganos que deben ser y aparentar ser imparciales» ${ }^{171}$,

Las instituciones señaladas: la inhibitoria como cuestión de competencia y, la recusación como cuestión de imparcialidad, están destinadas a garantizar la existencia de un juez competente e imparcial, respectivamente; estas dos instituciones han sido analizadas por la CIDH en la Sentencia de 05 de agosto de 2008, que se emitió en el Caso Apitz Barbera y otros vs. Venezuela de 5 de agosto de $2008^{172}$, fallo internacional en el que también se examinó el alcance de la imparcialidad en sus aspectos subjetivo y objetivo, de acuerdo a la doctrina desarrollada por la Corte Europea, antes comentado.

Dentro de la tramitación del proceso disciplinario -que dio lugar a la emisión de la indicada Sentencia emitida por la CIDH en el Caso Apitz Barbera y otros vs. Venezuela-, antes de la notificación con la destitución a los magistrados demandados, uno planteó recusación y otro inhibitoria en contra de los miembros del tribunal disciplinario (CFRSJ), la recusación no fue resuelta y se hizo mención a los casos en los que procede una inhibitoria; situación que ante la CIDH fue cuestionada en contra del Estado Venezolano, tanto por la CIDH como por las víctimas, como violación al derecho a un juez imparcial.

La CIDH considera que la recusación es: «un instrumento procesal destinado a proteger el derecho a ser juzgado por un órgano imparcial» ${ }^{173}$; a su vez, señala que la inhibición (inhibitoria): «no es suficiente para garantizar la imparcialidad del tribunal, puesto que no se ha demostrado que el justiciable tenga algún recurso para cuestionar al juez que debiendo inhibirse no lo

170 Párrafo 63.

171 Ibidem.

172 Este caso tiene como base fáctica el proceso administrativo disciplinario que llevó la Comisión de Funcionamiento y Reestructuración del Sistema Judicial» (CFRSJ) contra Juan Carlos Apitz Barbera y otros, como ex-jueces de la Corte Primera de lo Contencioso Administrativo, que terminó con sanción de destitución por haber incurrido en un error judicial inexcusable al conceder un amparo cautelar que suspendió los efectos de un acto administrativo (lo que generó reacciones adversas por parte de altos funcionarios del Poder Ejecutivo). La sanción de destitución se dio por haber incurrido en un supuesto error judicial inexcusable, cuando lo que existió fue una diferencia razonable y razonada de interpretaciones jurídicas posibles sobre una figura procesal determinada.

173 Párrafo 64. 
hiciere» ${ }^{174}$; en el caso concreto y luego de una valoración la Corte tras poner de relieve que: «sí está demostrado que su legislación ... les impidieron solicitar que la imparcialidad de su órgano juzgador sea revisada» ${ }^{175}$, por faltar la recusación en su legislación, concluyó que: «el Estado no garantizó el derecho de las víctimas a ser juzgadas por un tribunal imparcial, lo que constituye una violación del artículo 8.1 de la Convención» ${ }^{176}$.

Consiguientemente, la inhibitoria no garantiza la imparcialidad de un juez o tribunal, por ser la misma una cuestión de competencia y no una cuestión de imparcialidad. Al contrario, la recusación garantiza la imparcialidad del juzgador por ser una cuestión de imparcialidad o un medio procesal que tiene el justiciable para solicitar que su causa sea juzgada por un juez imparcial o respecto al cual no tenga duda razonable su de parcialidad; medio procesal que además puede ser utilizado cuando la autoridad jurisdiccional, debiendo inhibirse de conocer la causa -por falta de competencia- no lo hiciere; razón por la que se vulnera el derecho a un juez imparcial, en aquellos países en los que no existe esa herramienta procesal -recusación-.

La Sentencia antes comentada, emitida el año 2008, en el referido Caso Apitz Barbera y otros Vs. Venezuela, es la primera que analiza la imparcialidad subjetiva y objetiva del juzgador, conforme al desarrollo que al respecto se dio en el Tribunal Europeo; así como se complemento la reflexión con el alcance de dos instituciones jurídicas importantes como son la recusación e inhibitoria; antes de ese caso, los análisis que efectuó la Corte del tema del juez imparcial, están en íntima conexión a la exigencia de un juez competente, como se pasa a comentar.

El Tribunal Constitucional del Perú, en el Expediente n. ${ }^{\circ} 010-2002-\mathrm{AI} /$ TC, en el que se pronunció la Sentencia de 03 de enero de 2003, señaló que la: «recusación está destinada justamente a cuestionar la imparcialidad ... del juez en la resolución de la causa», violándose el derecho al juez natural imparcial: «si se restringiera irrazonablemente la posibilidad de recusar a los jueces del proceso, el ejercicio del derecho no encontraría posibilidad de manifestarse en los hechos» ${ }^{177}$, por esas razones declaró inconstitucional una norma ${ }^{178}$ : «al proscribir en forma absoluta la posibilidad de recusar a los magistrados y auxiliares de justicia intervinientes en la causa, incurre en una desproporcionada e irrazonable restricción del derecho al juez natural y es

\footnotetext{
174 Párrafo 65.

175 Párrafo 66.

176 Párrafo 67.

177 Punto 10.2.c.112.

178 El inciso h) del artículo 13. ${ }^{\circ}$ del Decreto Ley n. 25475.
} 
también inconstitucional» ${ }^{179}$; este fallo es anterior al emitido por la $\mathrm{CIDH}$ referido y aplicable a la situación de estudio.

Una vez más tenemos que hacer referencia a los tribunales militares. Desde una perspectiva objetiva, existen motivos por los que las partes tienen duda razonable sobre la parcialidad del juzgador, cuando militares activos participan de situaciones y con posterioridad juzgan a personas que han estado involucradas en ellas. El juzgador, no puede ser parte y juez al mismo tiempo. Así tratándose de las fuerzas armadas juegan un doble papel: por un lado conocen y deciden sobre una determinada situación (parte) y, por otra parte, la juzgan, lo que no satisface los requerimientos inherentes a las garantías de independencia y sobre todo de imparcialidad.

En el Caso Castillo Petruzzi y otros c. Perú, en mayo de 1999, se manifestó: «las propias fuerzas armadas inmersas en el combate contra los grupos insurgentes, son las encargadas del juzgamiento de las personas vinculadas a dichos grupos. Este extremo mina considerablemente la imparcialidad que debe tener el juzgador» ${ }^{180}$.

En el Caso Durand y Ugarte Vs. Perú, de16 de agosto de 2000, se indicó: «los tribunales que conocieron los hechos relacionados con dichos sucesos ... y los militares que integraban dichos tribunales eran, a su vez, miembros de las fuerzas armadas en servicio activo ... Por tanto, estaban incapacitados para rendir un dictamen independiente e imparcial» ${ }^{181}$.

En la misma línea, en el Caso Cantoral Benavides Vs. Perú, de 18 agosto de 2000, cuando se indicó que: «la imparcialidad del juzgador resulta afectada por el hecho de que las fuerzas armadas tengan la doble función de combatir militarmente a los grupos insurgentes y de juzgar e imponer penas a los miembros de dichos grupos» ${ }^{182}$.

En diciembre de 2001, en el Caso Las Palmeras Vs. Colombia (06 de diciembre de 2001), se ha extrañado la falta de imparcialidad, porque: «En el caso sub judice, las propias fuerzas armadas involucradas en el combate contra las grupos insurgentes, son los encargados de juzgar a sus mismos pares por la ejecución de civiles, tal y como lo reconoció el propio Estado» ${ }^{183}$.

El Tribunal Constitucional del Perú, en el Expediente EXP. n. ${ }^{\circ} 0023-$ 2003-AI/TC, que corresponde a una Sentencia de junio de 2004, asumió los razonamientos de la CIDH sobre la imparcialidad del juzgador, citando de manera expresa Caso Castillo Petruzzi, que se refiere a la imparcialidad del juzgador, señalando que: «el hecho de que los tribunales militares sean

179 Punto 10.2.c.113.

180 Párrafo 130.

181 Párrafo 126.

182 Párrafo 114.

183 Párrafo 53. 
conformados en su mayoría por «oficiales en actividad», vulnera los principios de ... imparcialidad de la función jurisdiccional» ${ }^{184}$;

Ese mismo razonamiento ha sido reiterado por ese Tribunal Constitucional del Perú, en el Expediente n. ${ }^{\circ}$ 0004-2006-PI/TC, en el que se emitió la Sentencia de marzo de 2006, en la que se señaló que: «el juez militar no puede desempeñarse, a la vez, como oficial en actividad de las fuerzas armadas ... la situación de actividad implica un nivel de pertenencia ... al respectivo instituto armado o policial y, en última instancia al Poder Ejecutivo» además el análisis concluyó con una apreciación lógica, en sentido de que: «no se podría afirmar que un juez especializado en lo penal militar es ... imparcial si existe la posibilidad de que este reciba, por ejemplo, beneficios asistenciales de salud, educación, vivienda y bienestar, por parte de las Fuerzas Armadas o la Policía Nacional» ${ }^{185}$.

Ciertamente, un militar activo y juzgador, difícilmente podría ser imparcial con la institución a la que pertenece, si de la misma recibe el trabajo, ascensos y otras ventajas. Al respecto resulta muy gráfico un cuestionamiento que se realizó el Tribunal Constitucional del Perú -con respuesta obvia-, cuando en el tantas veces referido Expediente n. ${ }^{\circ}$ 0004-2006-PI/TC en marzo de 2006 se pregunto: «¿Qué ... imparcialidad se podría asegurar a los propios efectivos militares que puedan ser procesados, si los jueces que los van a juzgar son oficiales en actividad y, en cuanto tales, pertenecen a la estructura castrense? La respuesta es obvia, ninguna ${ }^{186}$. Es importante destacar como en este tema, el Tribunal Constitucional del Perú ha recibido la jurisprudencia de la CIDH, de manera expresa, realizando la cita y del precedente correspondiente.

Ese mismo Tribunal Constitucional del Perú, emitió otra Sentencia, en 13 de junio de 2006, en el EXP n. ${ }^{\circ}$ 0006-2006-PI/TC, en la que también de manera expresa asumió y se refirió a los criterios que la CIDH dio en los Casos Durand y Ugarte vs. Perú (2000), Cantoral Benavides vs. Perú (2000), Tribunal Constitucional vs. Perú (2001), Palmeras vs. Colombia (2001), Lori Berenson vs. Perú (2004) y, Palamara Iribarne vs. Chile (2005), señalando que: «Respecto de los tribunales militares, la Corte ha sostenido, expresamente, que el hecho de que se encuentren compuestos por oficiales en actividad atenta contra la independencia e imparcial que debe tener toda autoridad que administre justicia» ${ }^{187}$.

A su vez, la Corte Constitucional del Colombia en la misma temática, ha manifestado que: «la imparcialidad exige que el proceso no sea afectado por

\footnotetext{
184 Punto 6.42.

185 Punto 2.2.68.

186 Ibídem.

187 Punto 1.12.
} 
personas que tengan algún interés o relación personal con el asunto. Sólo así puede protegerse a los ciudadanos de injerencias inadecuadas y opiniones anticipadas de parte de los funcionarios. Es obvio entonces que los militares no gozan de la imparcialidad exigida por la Carta y los pactos de derechos humanos cuando investigan penalmente a sus enemigos en un conflicto armado» ${ }^{188}$.

Esa apreciación la realizó haciendo mención a la garantía de imparcialidad, estudiada en varias ocasiones por la $\mathrm{CIDH}$, pese hacer referencia a ese organismo de protección internacional y asumir su criterio, no se señaló cual fuera el precedente que se asumió en el caso concreto.

\section{CONCLUSIONES}

El intercambio y el aprendizaje recíproco de la jurisprudencia entre tribunales hace que se profundice en el diálogo jurisprudencial entre la CIDH y el TEDH y entre ellos y los respectivos órganos de cierre de la jurisdicción constitucional de los Estados que conforman los sistemas americano y europeo de protección de los derechos humanos. Al TEDH y a la CIDH le corresponde fijar un mínimo común denominador que paulatinamente es asumido por los tribunales constitucionales. Aquí radica el germen de lo que podríamos denominar derecho global de protección de los derechos humanos.

La influencia entre TEDH y la CIDH es mutua pero del estudio del derecho al juez natural, se constata lo que, de momento, es la tónica general que no es otra que esa labor de armonización, en general, parte de la jurisprudencia del TEDH que se asume por la CIDH y a su vez, por los tribunales constitucionales de los diferentes Estados (en este estudio: España, Bolivia, Colombia y Perú), que son los principales interlocutores de dichos tribunales

Es una realidad que se está produciendo un entendimiento global de los derechos humanos, que se construye a partir de lo razonado en la jurisprudencia internacional, que establece los estándares mínimos comunes en materia de respeto y protección de los derechos humanos, jurisprudencia de mínimos que no debe ser considerada desde un punto de vista peyorativo de bajo nivel pues, las elaboraciones jurisprudenciales internacionales, en muchas ocasiones, fijan un listón de protección que es exigente. Ese listón mínimo puede e, incluso, debe ser superado por las interpretaciones que del derecho en cuestión hagan los tribunales estatales. Estos no deben ser considerados meros actores pasivos del diálogo sino que, al igual que existe una bidireccionalidad horizontal entre TEDH y CIDH, debe existir una bidireccionalidad vertical

188 Sentencia C-251/02. 
entre Tribunales supranacionales y tribunales estatales de tal suerte que las construcciones que estos elaboren que superen el estándar convencional deben ser asumidas tarde o temprano por aquellos, elevando así dicho estándar. Ello no obstante, hoy por hoy, la relación vertical es más bien un monólogo que un diálogo pues básicamente son el TEDH y la CIDH las que irradian sus construcciones doctrinales a los tribunales estatales detectándose muy pocos casos, aunque ya se han producido, a la inversa.

La formación del «derecho americano de los derechos humanos», se ha dado en forma paralela al desarrollo que se ha producido del «derecho europeo de los derechos humanos». Lo trascendente es la coincidencia casi absoluta en su contenido fruto de compartir una similar cultura jurídica ${ }^{189}$. No hay que pretender que haya que tender necesariamente hacia la uniformización sino hacia la compatibilidad de soluciones. Ejemplo de ello se da en relación con la posibilidad de jueces militares juzguen a civiles. Para la CIDH ello no es posible. Para el TEDH es posible en situaciones verdaderamente excepcionales que habrá que demostrar y con las garantías que establece el artículo 6.1. para todo tipo de procesos.

En consecuencia, ante la realidad expuesta puede afirmarse que asistimosal nacimiento de un «derecho global de los derechos humanos». Ahora bien, somos conscientes del pero para poder hablar de ello es necesario analizar otros sistemas como el africano en los que puede que el grado de coincidencia cultural no sea tan alto como el que se da entre Europa y América.

TITLE: Horizontal and vertical communication in the American and European systems of protection of human rights on the right to the natural judge. Towards a global right to human rights

RESUMEN: El análisis de los sistemas americanos de protección de derechos humanos ha permitido concluir la existencia de una comunicación vertical entre el tribunal supranacional y los tribunales estatales y una comunicación horizontal entre TEDH y CIDH. Estas relaciones han de ser bidireccionales. Y en Europa ya se han detectado algún caso de influencia de la jurisprudencia de un tribunal estatal en la del TEDH. Ello no obstante, sigue siendo predominante en ambos sistemas la influencia de arriba-abajo. En cuanto a la relación entre ambos sistemas aunque se da esa bidireccionalidad, hay que destacar que es mucho mayor la influencia del TEDH sobre la CIDH. Estas afirmaciones quedan constatadas mediante el estudio del derecho al juez natural.

PALABRAS CLAVE: Comunicación judicial horizontal y vertical, TEDH, CIDH, Juez natural.

${ }^{189}$ En este sentido vide GiUseppe de Vergottini, Más allá del diálogo..., 63 y 315. 
ABSTRACT: The analysis of the American systems of protection of the human rights has concluded in the existence of a vertical communication between the supranational court and the state courts and a horizontal communication between ECHR and IACHR. These relations must be bidirectional. And in Europe, some cases of jurisprudence influence have been already detected by a state court in the ECHR. It anyways continues being predominant the up-down influence in both systems. However the relation between both systems even there is this bidirectional setting, it is needed to starring the higher influence of the ECHR above the CIDH. These affirmations are constituted by the study of the right to the natural judge.

KEY WORDS: Horizontal and vertical communication, ECHR, IACHR, Natural Judge.

RECIBIDO: 20.09.2016

ACEPTADO: 30.05 .2017 